2. ECN Category
(mark one)
Supplemental

12a. Modification Work

[] Yes (fill out Blk. 12b)

[X] No (NA BIks. 12b, $12 c, 12 d)$

3. Originator's Name, Organization, MSIN, and Telephone No.

Todd M. Brown. Technical Basis

and Planning, R2-12, 373-4437

4. USQ Required?
[] Yes $[X]$ No

5. Date

6. Project Title/No./Work Order No.

7. Bldg./Sys./Fac. No.

$03 / 23 / 98$

High Priority Tank Sampling and Analysis Plan

9. Document Numbers Changed by this ECN (includes sheet no. and rev.) HNF-2337, Rev. 0

\begin{tabular}{c} 
N/A \\
\hline 10. Related ECN No(s). \\
N/A
\end{tabular}

8. Approval Designator

N/A

11. Related PO No.

\title{
N/A
}

12b. Work Package 12c. Modification Work Complete No.

$N / A$

$\mathrm{N} / \mathrm{A}$

12d. Restored to Original Condition (Temp. or Standby ECN only)

$$
\mathrm{N} / \mathrm{A}
$$

\section{3a. Description of Change}

Design Authority/cog. Engineer signature \& Date

13b. Design Baseline Document?
Design Authority/Cog. Engineer Signature \& Date

Complete revision.

14a. Justification (mark one)

Criteria change $[X]$ Design Improvement

As-Found Facilitate const

[] Environmental Const. Errorfomission

14b. Justification Details

This ECN was generated in order to incorporate comments received from the Defense Nuclear Facility Safety Board.

See attached distribution.
15. Distribution (include name, MSIN, and no. of copies)

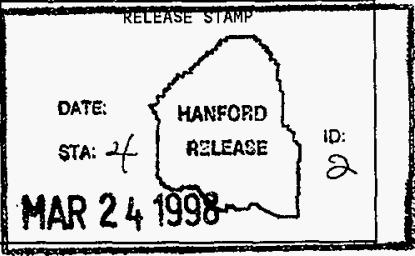




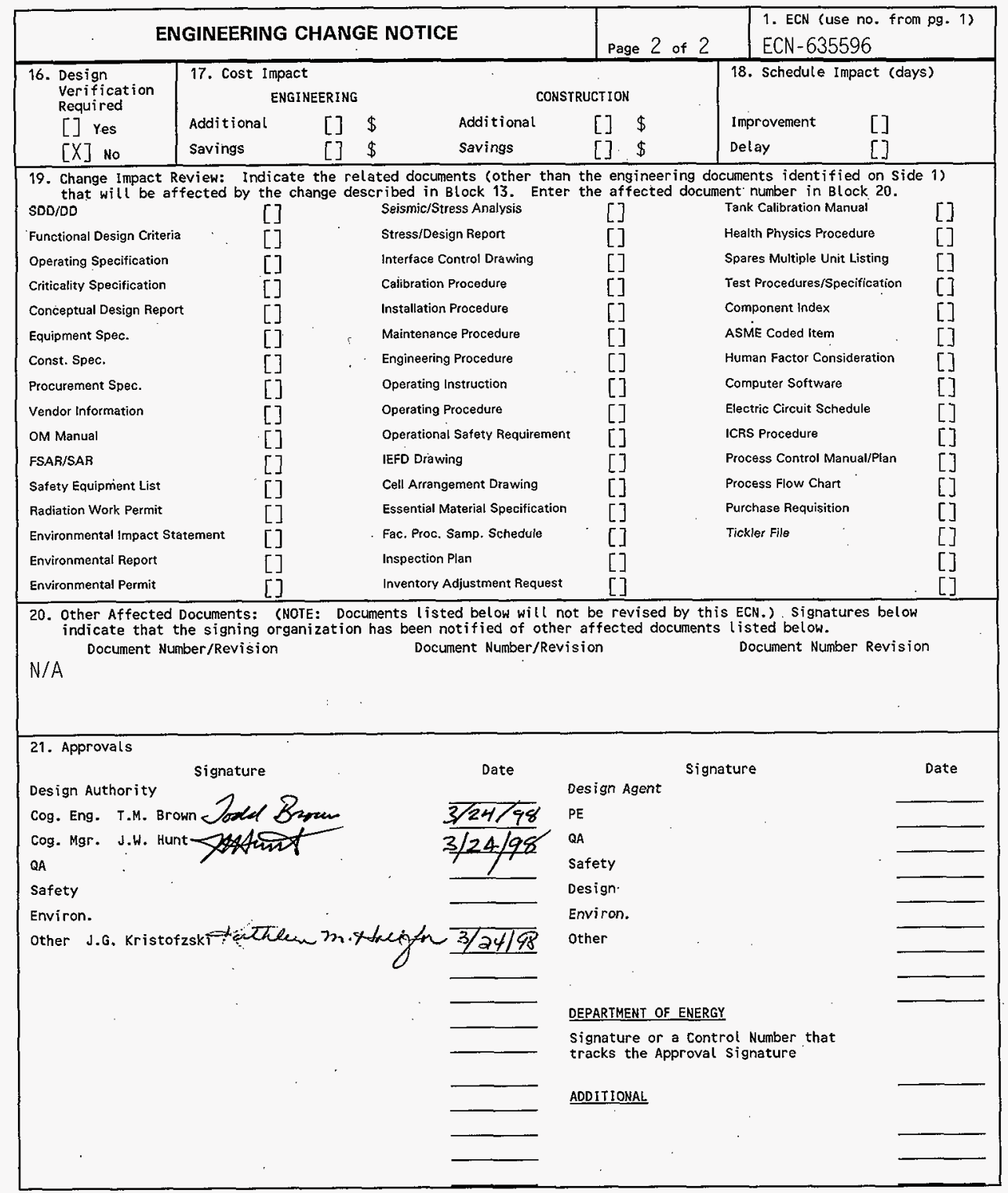




\section{High Priority Tank Sampling and Analysis Report}

Todd M. Brown

Lockheed Martin Hanford Corp., Richland, WA 99352

U.S. Department of Energy Contract DE-AC06-96RL13200

EDT/ECN: ECN-635596 UC: 2070

Org Code: 7A110 Charge Code: N4G2A

B\&R Code: EW 3120074 Total Pages: 59

Key Words: High Priority Tank, Sampling, Analysis; Report

Abstract: N/A

TRADEMARK DISCLAIMER. Reference herein to any specific commercial product, process, or service by trade name, trademark, manufacturer, or otherwise, does not necessarily constitute or imply its endorsement, recommendation, or favoring by the United States Government or any agency thereof or its contractors or subcontractors.

Printed in the United States of America. To obtain copies of this document, contact: Document Control Services, P.O. Box 950, Mailstop H6-08, Richland WA 99352, Phone (509) 372-2420; Fax (509) 376-4989.
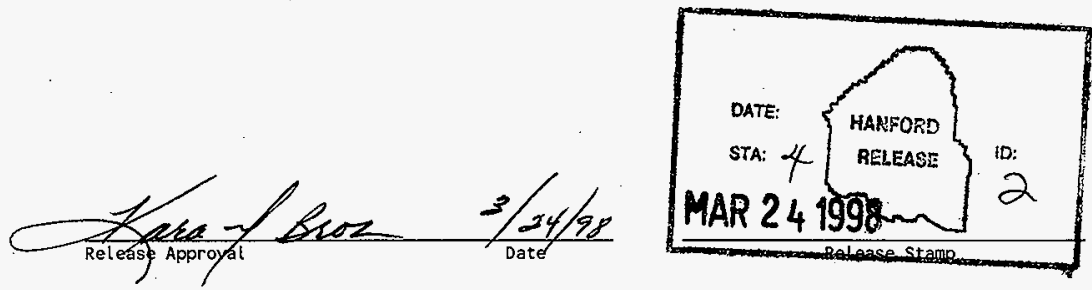

Approved for Public Release 


\section{RECORD OF REVISION}

(1). Docunent Number

HNF - 2337

Page 1

(2) Title

High Priority Tank Sampling and Analysis Plan

CHANGE CONTROL RECORD

\begin{tabular}{|c|cc|} 
(3) Revision & (4) Description of Change - Replace, Add, and Delete Pages \\
\hline 0 & (7) & $\begin{array}{l}\text { Injtially released 03/05/98 on EDT- } \\
622429 .\end{array}$ \\
\hline 1 RS & Incorporate per ECN-635596. \\
\hline
\end{tabular}

\begin{tabular}{|l|l|}
\hline \multicolumn{2}{|c|}{ Authorized for Release } \\
\hline (5) Cog. Engr. & (6) Cog. Mgr. Date \\
\hline T.M. Brown & J.W. Hunt \\
\hline
\end{tabular}




\title{
High Priority Tank Sampling and Analysis Report
}

\author{
T. M. Brown \\ J. W. Hunt \\ Lockheed Martin Hanford Corp. \\ L. J. Fergestrom \\ Technical Resources International \\ Date Published \\ March 1998
}

Prepared for the U.S. Department of Energy Assistant Secretary for Environmental Management

Fluor Daniel Hanford, Inc.

P.O. Box 1000

Richland, Washington

Hanford Management and Integration Contractor for the

U.S. Department of Energy under Contract DE-AC06-96RL13200 
HNF-2337 Rev. 1

\section{EXECUTIVE SUMMARY}

In July 1993, the Defense Nuclear Facilities Board issued Recommendation 93-5 (Conway 1993) which noted that there was insufficient tank waste technical information and the pace to obtain it was too slow to ensure that Hanford Site wastes could be safely stored, that associated operations could be conducted safely, and that future disposal data requirements could be met. In response, the U.S. Department of Energy, in May 1996, issued Revision 1 of the Recommendation 93-5 Implementation Plan (DOE-RL 1996). The Implementation Plan presented a modified approach to achieve the original plan's objectives, concentrating on actions necessary to ensure that wastes can be safely stored, that operations can be safely conducted, and that timely characterization information for the tank waste Disposal Program could be obtained.

The Implementation Plan proposed 28 High Priority tanks for near term core sampling and analysis, which along with sampling and analysis of other non-High Priority tanks, could provide the scientific and technical data to confirm assumptions, calibrate models, and measure safety related phenomenology of the waste. When the analysis results of the High Priority and other-tank sampling were reviewed, it was expected that a series of 12 questions, 9 related to safety issues and 3 related to planning for the disposal process, should be answered allowing key decisions to be made.

This report discusses the execution of the Implementation Plan and the results achieved in addressing the questions.

Through sampling and analysis, all nine safety related questions have been answered and extensive data for the three disposal planning related questions have been collected, allowing for key decision making.

Many more tanks than the original 28 High Priority tanks identified in the Implementation Plan were sampled and analyzed. Twenty-one High Priority tanks and 85 other tanks were core sampled and used to address the questions. Thirty-eight additional tanks were auger or grab sampled and used. A total of condensed phase samples from 144 tanks were used. Vapor samples for 82 of the tanks were used to address questions needing vapor analysis results. Additional High Priority and other tanks used to address specific questions provided comparable information to that expected from the original plan.

Simultaneously, a robust systems integrated approach for establishing near term sampling requirements has been established as part of the Tank Waste Remediation System's culture.

No further sampling and analysis will be conducted for the sole purpose of addressing the 12 questions in the Implementation Plan. Characterization sampling and analysis will continue in support of other requirements and decision making as identified through application of the systems integrated approach. 


\section{CONTENTS}

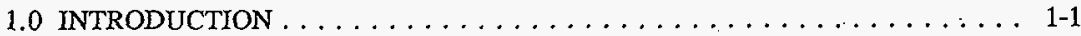

1.1 BACKGROUND . . . . . . . . . . . . . . . . . $1-1$

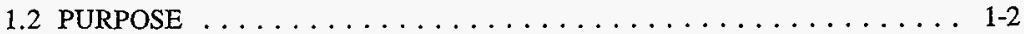

1.3 SAMPLING SUMMARY $\ldots \ldots \ldots \ldots \ldots \ldots \ldots \ldots \ldots \ldots \ldots$

2.0 CHARACTERIZATION TO SUPPORT QUESTIONS $\ldots \ldots \ldots \ldots \ldots \ldots .2-1$

2.1 ORIGINAL INTENT OF HIGH PRIORITY TANKS $\ldots \ldots \ldots \ldots . \ldots 2-1$

2.2 REQUIREMENTS DOCUMENTS USED TO ADDRESS THE

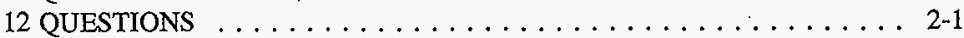

3.0 SAFETY AND DISPOSAL QUESTIONS $\ldots \ldots \ldots \ldots \ldots \ldots \ldots \ldots \ldots$ 3-1

3.1 FERROCYANIDE SAFETY ISSUE . . . . . . . . . . . . 3-1

3.1.1 Ferrocyanide Aging (Question \#1) $\ldots \ldots \ldots \ldots \ldots \ldots \ldots \ldots$ 3-1

3.1.2 Sampling and Analysis Summary for Ferrocyanide Question ..... 3-3

3.2 ORGANIC COMPLEXANT SAFETY ISSUE $\ldots \ldots \ldots \ldots \ldots \ldots \ldots . \ldots .4$

3.2.1 Organic Complexant Aging (Question \#2) $\ldots \ldots \ldots \ldots \ldots \ldots$ 3-5

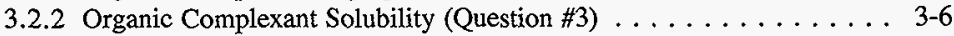

3.2.3 Moisture Retention (Question \#6) $\ldots \ldots \ldots \ldots \ldots \ldots \ldots \ldots$. . . . . . . .

3.2.4 Energetics/Moisture Criteria (Question \#8) $\ldots \ldots \ldots \ldots \ldots$. . . . .

3.2.5 Sampling and Analysis Summary for Organic

Complexant Questions . . . . . . . . . . . . . . 3-10

3.3 ORGANIC SOLVENT SAFETY ISSUE $\ldots \ldots \ldots \ldots \ldots \ldots \ldots \ldots$ 3-16

3.3.1 Relationship of Organic Solvents in Vapor and Solid/Liquid Phases (Question \#4) . . . . . . . . . . . . . . . 3-17

3.3.2 Location of Organic Solvents (Question \#5) . . . . . . . . . 3-18

3.3.3 Representativeness of Tank 241-C-103 Solvents to Other Tanks (Question \#9) . . . . . . . . . . . . . . . . . . . 3-20

3.3.4 Sampling and Analysis Summary for Organic Solvent Questions . . . 3-20

3.4 FLAMMABLE GAS SAFETY ISSUE $\ldots \ldots \ldots \ldots \ldots \ldots \ldots \ldots \ldots$. $\ldots \ldots \ldots$

3.4.1 Flammable Gas Retention (Question \#7) . . . . . . . . . . 3-24

3.4.2 Sampling and Analysis Summary for Flammable Gas Question . . . . 3-25

3.5 DISPOSAL PLANNING ISSUES $\ldots \ldots \ldots \ldots \ldots \ldots \ldots \ldots \ldots \ldots \ldots \ldots$

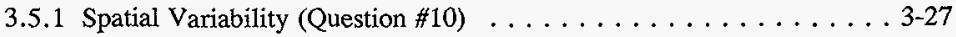

3.5.2 Saltcake Variability (Question \#11) . . . . . . . . . . . 3-28

3.5.3 Predictive Reliability of Process Models (Question \#12) . . . . . . 3-28

3.5.4 Sampling and Analysis Summary for Disposal Planning Questions . . . 3-30 
HNF-2337 Rev. 1

4.0 SAMPLING AND ANALYSIS SUMMARY AND CONCLUSIONS $\ldots \ldots \ldots$ 4-1

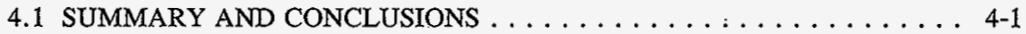

4.2 FUTURE CHARACTERIZATION $\ldots \ldots \ldots \ldots \ldots \ldots \ldots \ldots . \ldots .2$

5.0 REFERENCES $\ldots \ldots \ldots \ldots \ldots \ldots \ldots \ldots \ldots \ldots \ldots \ldots \ldots \ldots \ldots \ldots$ 5-1

\section{LIST OF FIGURES}

1-1 High Priority and Other Tanks Used to Address 12 Questions . . . . . . . . . 1-4

\section{LIST OF TABLES}

2-1 High Priority Tanks and 12 Questions - Original Intent of

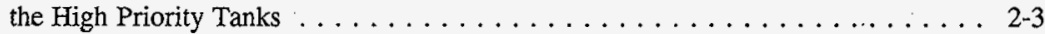

2-2 Requirements Documents Used to Address 12 Questions . . . . . . . . . . 2-5

3-1 Sample and Analysis Summary for Ferrocyanide Question $\ldots \ldots \ldots \ldots$. . . . 3-3

3-2 Sample and Analysis Summary for Organic Complexant Questions $\ldots \ldots \ldots$ 3-11

3-3 Sample and Analysis Summary for Organic Solvent Questions . . . . . . . 3-22

3-4 Sample and Analysis Summary for Flammable Gas Question $\ldots \ldots \ldots \ldots \ldots$ 3-26

3-5 Sample and Analysis Summary for Disposal Planning Questions . . . . . . . 3-31 


\section{LIST OF .TERMS}

\begin{tabular}{ll} 
ANOVA & analysis of variance \\
cm & centimeter \\
DBBP & dibutyl butylphosphonate \\
DNFSB & Defense Nuclear Facilities Safety Board \\
DOE & U.S. Department of Energy \\
DOE-RL & U.S. Department of Energy, Richland Operations Office \\
DQO & data quality objective \\
DST & double-shell tank \\
EDTA & ethylenediaminetetraacetic acid \\
FeCN & ferrocyanide \\
HDW & Hanford Defined Wastes \\
HEDTA & hydroxyethylethylenediaminetriacetic acid \\
HLW & high-level waste \\
HPT & High Priority tank \\
IC & ion chromatography \\
ICP & Inductively coupled plasma \\
IDA & iminodiacetic acid \\
J/g & Joules per gram \\
LAW & low-activity waste \\
m & square meter \\
MOU & memorandum of understanding \\
NPH & normal paraffin hydrocarbon \\
NTA & nitrilotriacetic acid \\
PUREX & Plutonium-Uranium Extraction Plant \\
RGS & retained gas sampler \\
REDOX & Reduction-Oxidation Plant \\
RSST & reactive system screening tool \\
SORWT & Sort on Radioactive Waste Type \\
SST & single-shell tank \\
TBP & tributyl phosphate \\
TCD & tank characterization database \\
TGA & thermogravimetric analysis \\
TOC & total organic carbon \\
VFI & void fraction instrument \\
wt\% & weight percent \\
$\mu \mathrm{g} / \mathrm{mL}$ & microgram per millititer \\
& \\
\hline
\end{tabular}




\subsection{INTRODUCTION}

\subsection{BACKGROUND}

In July 1993, the Defense Nuclear Facilities Safety Board (DNFSB) transmitted Recommendation 93-5 (Conway 1993) to the U.S. Department of Energy (DOE). Recommendation 93-5 noted that there was insufficient tank waste technical information and the pace to obtain it was too slow to ensure that Hanford Site wastes could be safely stored, that associated operations could be conducted safely, and that future disposal data requirements could be met.

In May 1996, the DOE issued Revision 1 of the Recommendation 93-5 Implementation Plan (DOE-RL 1996). The Implementation Plan revision presented a modified approach to achieve the original plan's objectives. The approach concentrated on actions necessary to ensure that wastes can be safely stored, that operations can be safely conducted, and that timely characterization information for the tank waste Disposal Program could be obtained. The Implementation Plan proposed 28 High Priority tanks, which, if sampled and analyzed, were expected to provide information to answer questions regarding safety and disposal issues. The High Priority tank list was originally developed in Section 9.0 of the Tank Waste Characterization Basis (Brown et al. 1995) by integrating the needs of the various safety and disposal programs. The High Priority tank list represents a set of tanks that were expected to provide the highest information return for characterization resources expended.

The High Priority tanks were selected for near-term core sampling and were not expected to be the only tanks that would provide meaningful information. Sampling and analysis of non-High Priority tanks also could be used to provide scientific and technical data to confirm assumptions, calibrate models, and measure safety related phenomenological characteristics of the waste.

When the sampling and analysis results of the High Priority and other tanks were reviewed, it was expected that a series of questions should be answered allowing key decisions to be made. The first nine questions related to safety issues and the last three questions related to planning for the disposal process (retrieval, treatment, and immobilization). The 12 questions are listed as follows:

\section{Safety Related Questions}

1. Does sample analysis confirm the model that ferrocyanide decomposes in the waste tanks into less reactive compounds?

2. Does sample analysis confirm the model that organic complexants decompose?

3. Does sample analysis confirm that organic complexants are soluble in water? 
4. Does detection of organic solvents in the vapor phase correspond to presence of the solvents in the liquid or solid phases?

5. Does sample analysis confirm the anticipated locations of organic solvents within the liquid and solid waste (surface layers, interfaces, entrained)?

6. Does sample analysis establish an authoritative basis for understanding moisture retention in saltcake and in sludge?

7. Does sample analysis provide a basis for determining the amount and composition of retained gases in the bounding flammable gas tanks?

8. Does the sample analysis confirm the postulated energetics and moisture criteria for propagation of fuel/oxidizer reactions?

9. Does the sample analysis confirm that the solvents found in tank 241-C-103 are representative of solvents found in other tanks?

\section{Disposal Planning Related Questions}

10. What is the degree of spatial variability and level of resolution observed in a highly variable tank and in a homogeneous tank?

11. What is the range of compositional variability observed in saltcake?

12. How well do the models of the key waste type compositions compare with the observed compositions?

Throughout the rest of this report, the 12 questions are grouped by safety and disposal related issues. Question \#1 addresses the Ferrocyanide Safety Issue. Questions \#2, 3, 6, and 8 address the Organic Complexant Safety Issue. Questions \#4, 5, and 9 address the Organic Solvent Safety Issue. Question \#7 addresses the Flammable Gas Safety Issue. Questions \#10, 11 , and 12 address the Disposal issues.

\subsection{PURPOSE}

This report describes how the sampling and analysis of High Priority and other tanks has been used to answer the safety and disposal questions listed in Section 1.1 allowing key decisions to be made. The report documents the success achieved in providing scientific and technical data to confirm assumptions, calibrate models, and measure safety related phenomenological characteristics of the waste and reflects the greater amount of work accomplished than was originally intended. 
When the Implementation Plan was issued in May 1996, each of the High Priority tanks was selected to satisfy information needs of one or more of the safety and disposal related questions. Section 2.0 of this report summarizes the original intent of High Priority tank sampling; specifically; which High Priority tanks were intended to address each of the 12 questions. Section 2.0 also discusses the requirements documents that were used to conduct characterization to answer the 12 questions.

Section 3.0 provides a synopsis of the results of sampling and analysis as applied to the 12 safety and disposal related questions. The questions have been answered using the sampling and analysis of High Priority and other tanks. No further characterization effort is needed to answer the specific 12 questions. However, a robust systems approach for establishing other near-term sampling requirements has been established as part of the culture of the Tank Waste Remediation System.

Section 4.0 of this report summarizes sampling and analysis conducted and conclusions reached.

\subsection{SAMPLING SUMMARY}

Figure 1-1, below, provides a summary of High Priority and other tanks sampled and analyzed to provide scientific and technical data to confirm assumptions, calibrate models and measure safety related phenonmenological characteristics of the waste. Note that for every question, the number of tanks sampled and analyzed exceeds the number originally planned. 
Figure 1-1. High Priority and Other Tanks Used to Address 12 Questions.

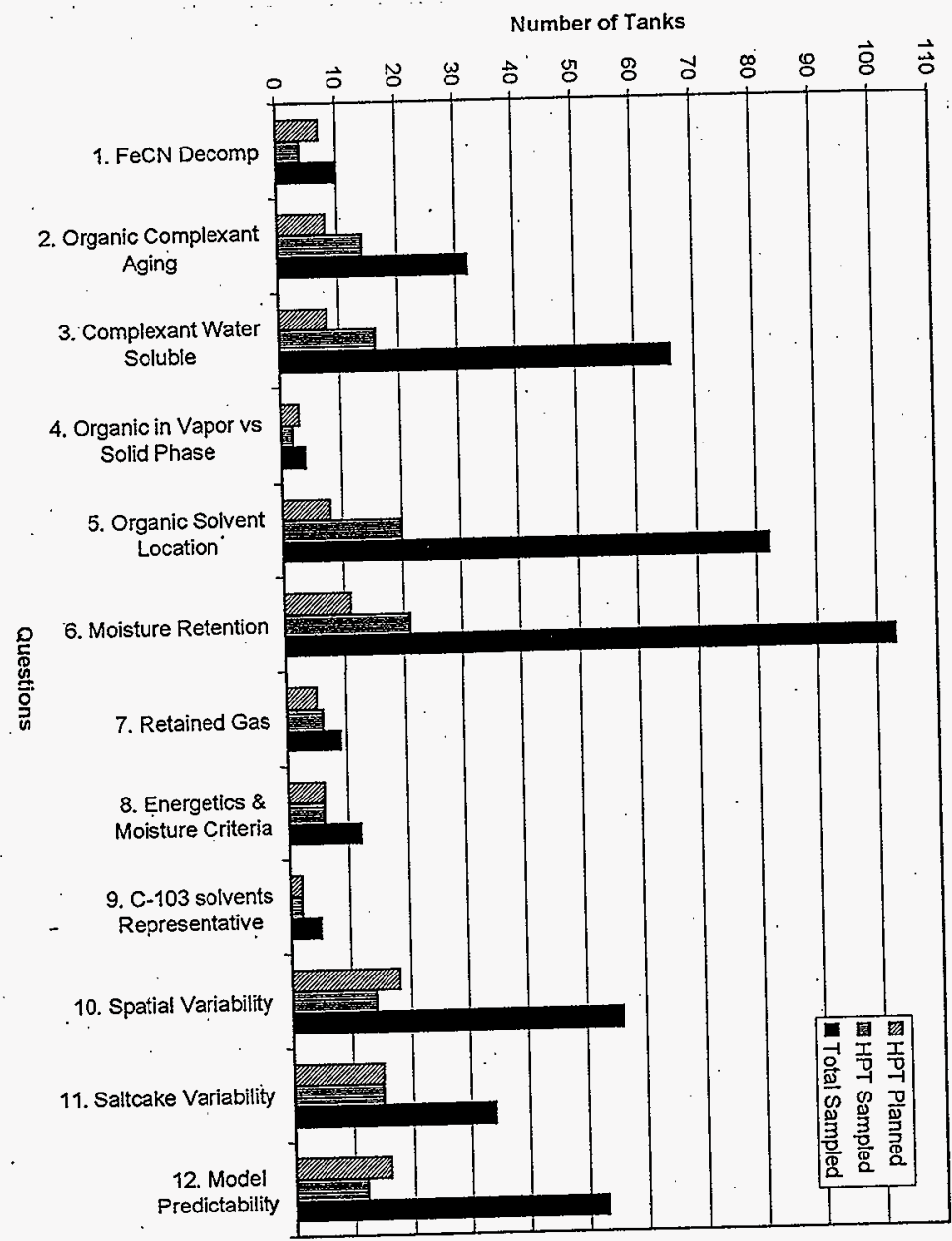


HNF-2337 Rev. 1

\subsection{CHARACTERIZATION TO SUPPORT QUESTIONS}

This section discusses the original intent of the High Priority tanks and summarizes characterization requirements documents used to address the 12 questions listed in Section 1.1. Section 2.1 discusses the methodology used to select the High Priority tanks, and which of the 12 questions each High Priority tank was intended to address. Section 2.2 discusses the characterization requirements planning documentation that has been used to address the 12. questions since the release of Recommendation 93-5 Implementation Plan (DOE-RL 1996).

\subsection{ORIGINAL INTENT OF HIGH PRIORITY TANKS}

The DNFSB recommended (Conway 1993) that priorities in schedule be given to Watch List tanks and other tanks with identified safety problems, and priority to the chemical analyses providing information important to ensuring safety in the near term. Also noted was that analyses for long-term disposition of the waste could be postponed until more pressing safetyrelated analyses were completed. Subsequently, the Tank Waste Characterization Basis (Brown et al. 1995) was developed to identify tanks with potential to best address safety and disposal issues. Issue priorities were determined by a panel consisting of representatives of the safety and disposal programs, the U. S. Department of Energy, Richland Operations Office and the Washington State Department of Ecology. Criteria were developed by each program to determine which tanks likely would, if sampled, provide the most useful information for each issue. Issue weighting factors and tank selection criteria were used to create a priority list of all 177 Hanford Site underground storage tanks. From the list, 28 High Priority tanks were selected for near-term core sampling. Analyses of samples from these tanks were expected to resolve or bound the key questions.

The High Priority tanks were listed in Appendix F of Recommendation 93-5 Implementation Plan (DOE-RL 1996), along with the questions in Appendix J. The High Priority tanks as they were applied to the 12 questions are summarized in Table 2-1. Column one lists the 28 High Priority tanks. The remaining columns represent the 12 questions. An " $\mathrm{X}$ " in the table signifies that the High Priority tank was originally intended to be used to address the question.

\subsection{REQUIREMENTS DOCUMENTS USED TO ADDRESS THE 12 QUESTIONS}

To integrate program needs when performing characterization operations, the safety and disposal programs described their sampling and analysis requirements in Data Quality Objective (DQO) reports, letters, memoranda of understanding, and test plans. Information needs from these documents were integrated in tank specific sampling and analysis plans before taking or analyzing samples from a tank. Requirements documents that describe the information needs to address the 12 questions are listed in Table 2-2. The documents sometimes addressed the sampling and analytical needs for more than one of the 12 questions. 
Column 1 in Table 2-2 lists the requirements documents. The remaining columns represent the 12 questions. An " $X$ " in the table signifies that the requirements document described sampling and/or analysis to address the question. 
Table 2-1. High Priority Tanks and 12 Questions - Original Intent of the High Priority Tanks. (2 sheets)

\begin{tabular}{|c|c|c|c|c|c|c|c|c|c|c|c|c|}
\hline 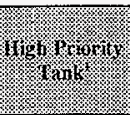 & king & 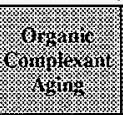 & 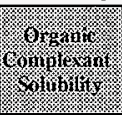 & 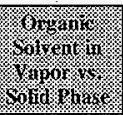 & 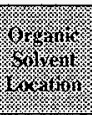 & 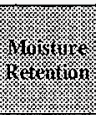 & 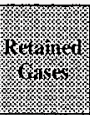 & 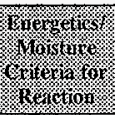 & 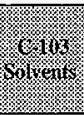 & 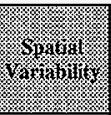 & 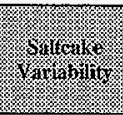 & 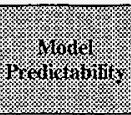 \\
\hline A-101 & & & & & & & $x$ & & & $\mathrm{X}$ & $X$ & $X$ \\
\hline AN-103 & & & & & . & & $X$ & $X$ & & & & \\
\hline$A N-104$ & & & & & & & $x$ & $\mathrm{X}$. & & & & \\
\hline$A N-105$ & & & & & & & $\dot{x}$ & $\mathrm{X}$ & & & & \\
\hline AW-101 & & & & & & & $X$ & $X$ & & & & \\
\hline AX-101 & & & & & & & & & & $\mathrm{X}$ & $\mathrm{X}$ & $X$ \\
\hline B-104 & & & & & & & & & & $X$ & & $x$ \\
\hline BY-103 & $\mathrm{X}$ & $x$ & $\mathrm{X}$ & $\mathrm{X}$ & $\mathrm{X}$ & $\mathrm{X}$ & & $\mathrm{X}$ & & $\mathrm{X}$ & $\mathrm{X}$ & \\
\hline BY-104 & $\mathrm{X}$ & & & & & $\mathrm{X}$ & & $\mathrm{X}$ & & $X$ & $X$ & $x$ \\
\hline BY-105 & $X$ & $\mathrm{X}$ & $X$ & & $\mathrm{X}$ & $X$ & & & & $\mathrm{X}$ & $\mathrm{X}$ & \\
\hline BY-106 & $\mathrm{X}$ & $\mathrm{X}$ & $X$ & & $\mathrm{X}$ & $\mathrm{X}$ & & & & & & \\
\hline BY-108 & $\mathrm{X}$ & $\mathrm{X}$ & $\mathrm{X}$ & $\mathrm{X}$ & $\mathrm{X}$ & $\mathrm{X}$ & & & $X$ & & & \\
\hline$B Y-110$ & $\mathrm{X}$ & & & $\mathrm{X}$ & & $x$ & & & $X$ & $\mathrm{X}$ & $X$ & $X$ \\
\hline C-104 & & & & & & & & & & $\mathrm{X}$ & & $X$ \\
\hline S-101 & & & & & & & & & & $X$ & $\mathrm{X}$ & $X$ \\
\hline$S-102$ & & & & & & & $\cdot$ & & & $X$ & $X$ & \\
\hline S-107 & & & & & & & & & & $X$ & & $\mathrm{X}$ \\
\hline$s-110$ & & & & & & & & & & $\mathrm{X}$ & $\mathrm{X}$ & $\mathrm{X}$ \\
\hline SX-101 & & & . & & & & & & & $\mathrm{X}$ & $\mathrm{X}$ & $\mathrm{X}$ \\
\hline SX-103 & & & & & & & & & & $\mathbf{X}$ & $\mathrm{X}$ & $\mathrm{X}$ \\
\hline SX-104 & & & & & & & & & & $X$ & $\mathrm{X}$ & $\mathrm{X}$ \\
\hline
\end{tabular}


Table 2-1. High Priority Tanks and 12 Questions - Original Intent of the High Priority Tanks. (2 sheets)

\begin{tabular}{|c|c|c|c|c|c|c|c|c|c|c|c|c|}
\hline 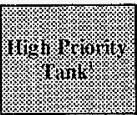 & 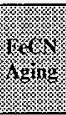 & 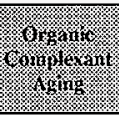 & 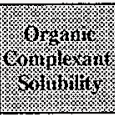 & 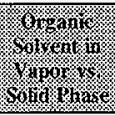 & 多on & proving & 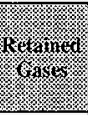 & 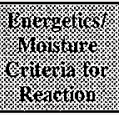 & 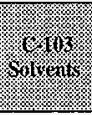 & 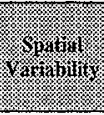 & 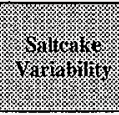 & 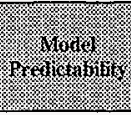 \\
\hline TX-111 & & & & & & & & & & & $X$ & $\mathrm{X}$ \\
\hline TX-118 & & & & & & & & & & & $X$ & $X$ \\
\hline TY-103 & $x$ & & & & & $X$ & & & & & & \\
\hline U-105 & & $\mathrm{X}$ & $\mathrm{X}$ & & $\mathrm{X}$ & $X$ & & & & $X$ & & $\mathrm{X}$ \\
\hline U-107 & & $\mathrm{X}$ & $\mathrm{X}$ & & $x$ & $X$ & & & & & & \\
\hline U-108 & & $\mathrm{X}$ & $\mathrm{X}$ & & $\mathrm{X}$ & $X$ & & & & $X$ & & $\mathrm{X}$ \\
\hline U-109 & & $\mathrm{X}$ & $\mathrm{X}$ & & $\mathrm{X}$ & $X$ & & & & $X$ & $X$ & \\
\hline
\end{tabular}

Notes:

${ }_{1}^{1}$ Tank U-103 was not originally listed in Appendix F of the 93-5 Implementation Plan (DOE-RL 1996) as one of the High Priority tanks. However, in Section 3.4 of the report attached to Wagoner (1997), tank U-103 was added to the High Priority tank list as replacement for tank TY-103. Tank U-103 is not included in this table

because it has not been recognized in any document as being chosen to address any one of the 12 questions specifically. Although tank TY-103 was removed from the list, it is included in this table and throughout the report to show the basis for its removal. 
Table 2-2. Requirements Documents Used to Address 12 Questions. (3 sheets)

\begin{tabular}{|c|c|c|c|c|c|c|c|c|c|c|c|c|}
\hline 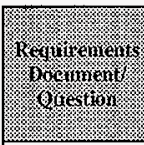 & 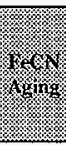 & 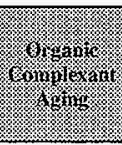 & 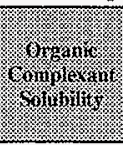 & 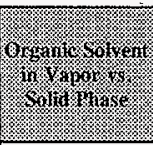 & 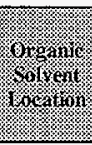 & 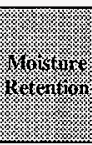 & 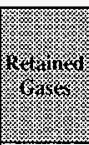 & 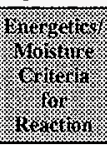 & 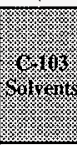 & 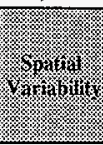 & 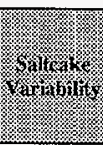 & 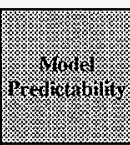 \\
\hline FeCN DQO ${ }^{1}$ & $\mathrm{X}$ & & & & & & & & & & & \\
\hline $\begin{array}{l}\text { Organic/FeCN } \\
\text { Test Plan }\end{array}$ & $\mathrm{X}$ & $X$ & $x$ & $\mathrm{X}$ & $X$ & & & & & & & \\
\hline $\begin{array}{l}\text { Organic } \\
\text { Complexant } \\
\mathrm{DQO}^{3}\end{array}$ & & $x$ & & & & & & & & & & \\
\hline $\begin{array}{l}\text { Organic } \\
\text { Complexant } \\
\text { Letter } \$ 1^{4}\end{array}$ & & $x$ & $X$ & . & & & & & & & & \\
\hline $\begin{array}{l}\text { Organic } \\
\text { Complexant } \\
\text { Letter } \sharp 2^{5}\end{array}$ & & $X$ & & & & & & & & & & \\
\hline $\begin{array}{l}\text { Organic } \\
\text { Complexant } \\
\text { MOU }^{6}\end{array}$ & & $\mathrm{X}$ & $\mathrm{X}$ & & & $x$ & & & & & & \\
\hline
\end{tabular}


Table 2-2. Requirements Documents Used to Address 12 Questions. (3 sheets)

\begin{tabular}{|c|c|c|c|c|c|c|c|c|c|c|c|c|}
\hline 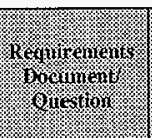 & s.t. & 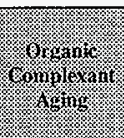 & 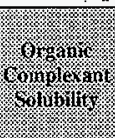 & 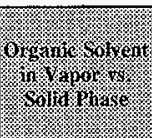 & 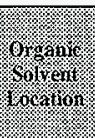 & 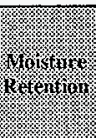 & 3roting & 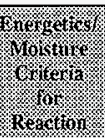 & 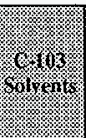 & 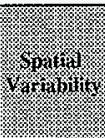 & 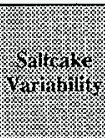 & 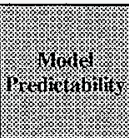 \\
\hline $\begin{array}{l}\text { Compatibility } \\
\text { DQO }\end{array}$ & & & $X$ & & & & & & & & & \\
\hline \begin{tabular}{|l|} 
Safety \\
Screening \\
DQO $^{8}$
\end{tabular} & & & & . & & $\mathrm{X}$ & & $\mathrm{X}$ & & & & \\
\hline $\begin{array}{l}\text { Hazardous } \\
\text { Vapor DQO }\end{array}$ & & & & $x$ & & & & & $\mathrm{x}$ & & . & \\
\hline $\begin{array}{l}\text { Organic Solvent } \\
\text { Letter }^{10}\end{array}$ & & & & $x$ & & & & & & & & \\
\hline $\begin{array}{l}\text { Organic Solvent } \\
\text { DQO } 11 .\end{array}$ & & & & $x$ & $x$ & & & & . & & & \\
\hline \begin{tabular}{|l|}
$\begin{array}{l}\text { Flammable Gas } \\
\text { DQO }^{12}\end{array}$ \\
\end{tabular} & & & & & & & $x$ & & & & & \\
\hline $\begin{array}{l}\text { Flammable Gas } \\
\text { Letter }^{13}\end{array}$ & & & & & & & $x$ & & & & . & \\
\hline
\end{tabular}




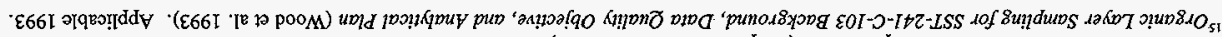

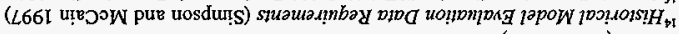

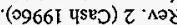

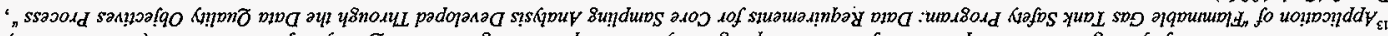

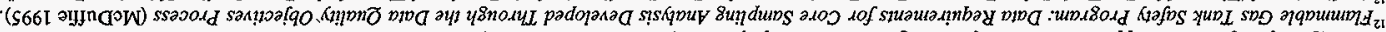

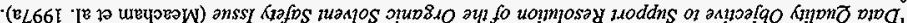

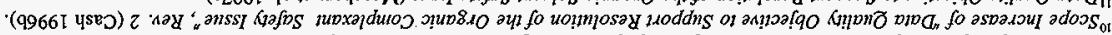

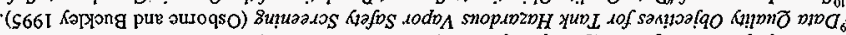

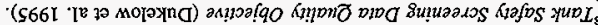

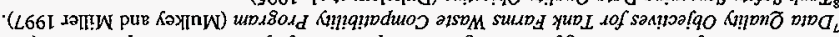

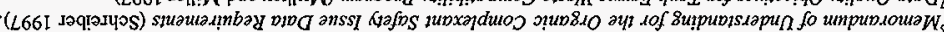

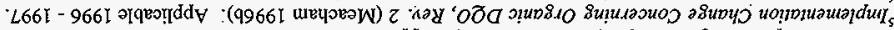
L66I - 966I गqएo! !d

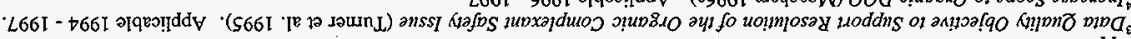

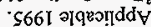

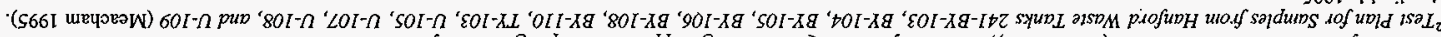

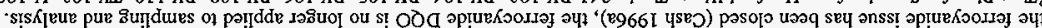

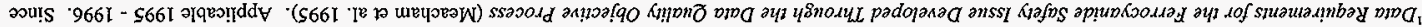

\begin{tabular}{|c|c|c|c|c|c|c|c|c|c|c|c|c|}
\hline & & & $\mathrm{X}$ & & & & & & & & & ${ }_{51} 000$ हOI-D \\
\hline $\mathrm{X}$ & x & $X$ & & & & & & & & & & $\underset{ }{{ }_{\mathrm{r}} \mathrm{OOO}}$ \\
\hline 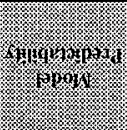 & 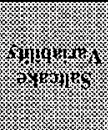 & 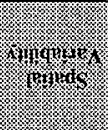 & 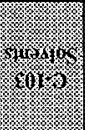 & 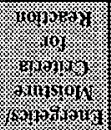 & 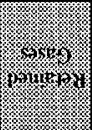 & 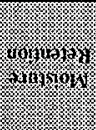 & 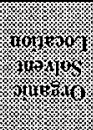 & 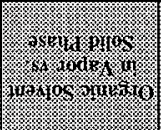 & 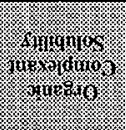 & 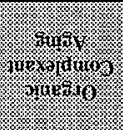 & 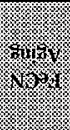 & 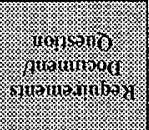 \\
\hline
\end{tabular}

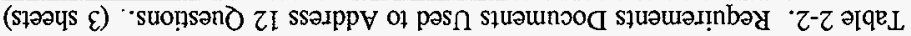




\subsection{SAFETY AND DISPOSAL QUESTIONS}

This section discusses the resolution of the 12 safety and disposal questions listed in Appendix $J$ of the Recommendation 93-5 Implementation Plan (DOE-RL 1996). The 12 questions are grouped into their respective safety or disposal issues (ferrocyanide, organic complexant, organic solvent, flammable gas, or disposal). Each of the following major sections summarizes one of the five safety or disposal issues. Each major sub-section under the safety or disposal issue summarizes one of the 12 questions.

Each question and an amplification of its purpose is shown in italics as a direct quote from the Recommendation 93-5 Implementation Plan. Immediately following is the answer to the question.

The first sub-section listed for each question is background. The background summarizes work other than sampling performed to develop a hypothesis or to support answering the question. The second sub-section, Sampling and Analysis, summarizes characterization sampling and analysis used to answer the question. The second sub-section shows how the sampling and analysis performed on real waste confirms hypotheses developed.

\subsection{FERROCYANDE SAFETY ISSUE}

Sufficient concentrations of ferrocyanide, in the presence of oxidizing material such as sodium nitrate, can react exothermically if heated to sufficiently high temperatures or subjected to a credible initiator of sufficient energy. Under certain conditions, reactions of this material can result in explosive energy releases. The ferrocyanide issue was resolved through gaining an understanding of the sodium nickel ferrocyanide aging phenomenon.

\subsubsection{Ferrocyanide Aging (Question \#1)}

- Does sample analysis confirm the model that ferrocyanide decomposes in the waste tanks into less reactive compounds?

If the results confirm this model (and all sample results to date are consistent with the model), then the ferrocyanide safety issue may be resolved for all tanks without further sampling.

Sampling and analysis of ferrocyanide tanks confirms the model that ferrocyanide decomposes in the waste tanks into less reactive compounds. Seven High Priority tanks were originally selected to answer the question. Ten tanks actually were used, of which four were High Priority tanks to include four of the original selections. The additional six other tanks 
provided comparable information to that expected from the three tanks originally selected but not used.

3.1.1.1 Background. Twenty-four tanks were initially identified as potentially containing sufficient ferrocyanide to be of concern. After review, it was determined that six of those tanks did not receive enough ferrocyanide to be of concern. Therefore, 18 ferrocyanide tanks were placed on the ferrocyanide Watch List; tanks BY-103, BY-104, BY-105, BY-106, BY-107, BY-108, BY-110, BY-111, BY-112, C-108, C-109, C-111, C-112, T-107, TX-118, TY-101, TY-103, and TY-104.

Information from literature searches, experiments, and analysis improved the understanding of the ferrocyanide hazard. A literature search revealed work that indicated that sodium nickel ferrocyanide decomposed (aged) to lower energy compounds when exposed to a typical Hanford Site tank environment (Babad et al. 1993). Studies with waste simulants corroborate that ferrocyanide decomposes under waste tank conditions (Lilga et al. 1993, 1994, and 1995). Three parameters (temperature, exposure to high $\mathrm{pH}$, and radiation dose) strongly affect the rate of decomposition. With the hypothesis that ferrocyanide decomposes to lower energy and less reactive compounds, tanks were selected for sampling and analysis to bound the conditions of ferrocyanide decomposition. If the decomposition phenomenon occurred in these tanks, then it occurred in all the ferrocyanide-containing waste. The decomposition phenomenon was to be confirmed by analyzing waste samples for ferrocyanide energy levels and nickel. If nickel is present and the energy levels are low, then the ferrocyanide has decomposed.

3.1.1.2 Sampling and Analysis (See Table 3-1). Analysis of the first two tanks sampled (C-109 and C-112) showed ferrocyanide concentrations 10 times lower than the original process flowsheets. This finding corroborated the results of ongoing aging experiments. By December 1993, it was recognized that the sampling and analysis of selected tank waste could answer the question of ferrocyanide aging.

Seven High Priority tanks were selected from the ferrocyanide Watch List to answer question \#1; tanks BY-103, BY-104, BY-105, BY-106, BY-108, BY-110, and TY-103. High Priority plus other tanks actually sampled and analyzed to answer the ferrocyanide question were BY-104, BY-106, BY-108, BY-110 (all High Priority tanks), plus C-108, C-109, C-111, C-112, T-107, and TY-104.

High Priority tanks BY-103, BY-105, and TY-103 were not sampled for ferrocyanide aging purposes because they were not needed to ultimately resolve the issue.

Tank waste nickel analysis confirmed that the sodium nickel ferrocyanide had been in the tanks as predicted and cyanide analysis confirmed the aging models by showing the cyanide levels were 10 times below that predicted. Statistical studies of the analysis results further confirm that the nickel present in the waste is indicative of the original ferrocyanide in the tanks and that the original ferrocyanide present degraded. 
Subsequently, the ferrocyanide unreviewed safety question and safety issue were closed. A detailed discussion of the process logic and reasoning behind the closure of this issue is found in Assessment of the Potential for Ferrocyanide Propagating Reaction Accidents (Meacham et al. 1996).

\subsubsection{Sampling and Analysis Summary for Ferrocyanide Question}

Table 3-1 summarizes the sampling and analysis performed for the ferrocyanide safety question. The first column of Table 3-1 lists the High Priority tanks that were originally intended to be used for the ferrocyanide question plus other tanks that actually were used to answer the question. High Priority tanks are denoted with an " $\mathrm{X}$ " in the second column. The sampling status of the tanks is shown in the third column. The fourth column depicts which tanks were sampled and analyzed for cyanide and nickel and therefore, used to determine if ferrocyanide aging occurred. Gray shading indicates that, in Appendix F of the Recommendation 93-5 Implementation Plan (DOE-RL 1996), a tank was originally intended in to be used to address the ferrocyanide aging question. The table cells indicate whether or not a tank was "Used" to address the question.

Table 3-1. Sample and Analysis Summary for Ferrocyanide Question. (2 sheets)

\begin{tabular}{|c|c|c|c|}
\hline (2) & 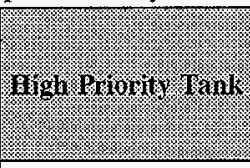 & (ane Sampling & 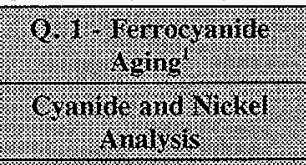 \\
\hline BY-103 & $\mathrm{X}$ & Unsampled & 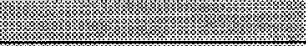 \\
\hline BY-104 & $\mathrm{X}$ & Sampled & IV \\
\hline BY-105 & $\mathrm{X}$ & Partially sampled & 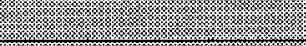 \\
\hline BY-106 & $\mathrm{X}$ & Sampled & rysex \\
\hline BY-108 & $\bar{x}$ & Sampled & 1.sed: \\
\hline BY-110 & $\mathrm{X}$ & Sampled & KISE \\
\hline TY-103 & $\mathrm{X}$ & Unsampled & 28 \\
\hline $\mathrm{C}-108$ & & Sampled & Used \\
\hline C-109 & & Sampled & Used \\
\hline C-111 & & Sampled & Used \\
\hline
\end{tabular}


Table 3-1. Sample and Analysis Summary for Ferrocyanide Question. (2 sheets)

\begin{tabular}{|c|c|c|c|}
\hline (1) & 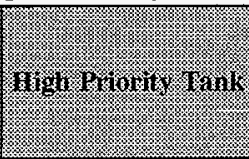 & 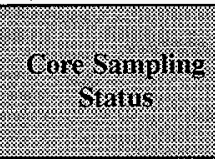 & U. \\
\hline $\mathrm{C}-112$ & & Sampled & Used \\
\hline $\mathrm{T}-107$ & & Sampled & Used \\
\hline \multirow[t]{4}{*}{ TY-104 } & & Sampled & Used \\
\hline & & & 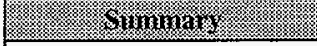 \\
\hline & & & $\begin{array}{lr}\text { High Priority Tanks } & \text { Originally } \\
\text { Intended: } & 7 \\
\text { Original High Priority Tanks } \\
\text { Used: } & 4 \\
\text { Total High Priority Tanks } & \\
\text { Used: } & 4 \\
\text { Other Tanks Used: } & 6\end{array}$ \\
\hline & & & Total Tanks Used: $\quad 10$ \\
\hline
\end{tabular}

Notes:

${ }^{1}$ Shading indicates that the tank was originally intended in Appendix F of the Recommendation 93-5 Implemenzation Plan (DOE-RL 1996) to be used to address the question.

\subsection{ORGANIC COMPLEXANT SAFETY ISSUE}

Sufficient concentrations of organic compounds and their decomposition products have the potential to react exothermically when combined with nitrate/nitrite oxidizer. The key to ensuring that organic complexants are safely stored is either to determine if sufficient material is present to support a propagating exothermic reaction or to ensure that there are no credible initiators to raise tank waste temperatures to reaction thresholds. Organic complexant and solvent degradation products have been widely distributed in the tanks as a result of waste management activities (Agnew 1996).

Energetics and moisture criteria (question \#8) were developed to screen tanks based on sample analysis results of water and total organic carbon (TOC). Understanding waste conditions that support combustion, coupled with organic complexant aging (question \#2), organic complexant solubility (question \#3), and the phenomenon of organic waste dry out/moisture retention (question \#6), permits addressing the issue. 


\subsubsection{Organic Complexant Aging (Question \#2)}

- Does sample analysis confirm the model that organic complexants decompose?

If the results confirm the model and the degree of decomposition can be well enough modeled, reduction in some organic controls may be allowed. Additional tank-by-tank sampling for organics may be limited to far fewer tanks.

Sampling and analysis of organic tanks confirms the model that organic complexants in a high-radiation, high-alkaline environment decompose. Eight High Priority tanks were originally selected to answer the question. Thirty-two tanks actually were used, of which 14 were High Priority tanks to include 7 of the original selections. The additional $25 \mathrm{High}$ Priority or other tanks provided comparable information to that expected from the one tank originally selected but not used.

3.2.1.1 Background. Theory, waste simulant experiments, and waste sample and analysis all show that organic complexants degrade in the tanks. The most recent summary of what has been learned about organic degradation is discussed in the Organic Complexant Topical Report (Meacham et al. 1997b). The information in this section summarizes Meacham et al.(1997b).

Wastes containing organic complexants have been stored in Hanford Site waste tanks for more than 17 years, during which time the complexants have been exposed to radiation, high temperatures, and a reactive chemical environment. Experiments with waste simulants (Camaioni et al. 1994, 1995, 1996, and 1998) show that organic complexants age to lower energy forms when exposed to heat and/or radiation in an environment similar to the waste tanks. The major organic complexants, hydroxyethylethylenediaminetriacetic acid (HEDTA), ethylenediaminetetraacetic acid (EDTA), citrate, and glycolate degraded to low energy products such as carbonate, formate, and oxalate. Because temperature and radiation vary among tanks, the degree of organic aging also varies.

3.2.1.2 Sampling and Analysis (See Table 3-2). Sampling and analysis has been used to confirm the model of organic aging. Organic speciation was used. Results are summarized in the following paragraphs.

A measure of the extent of organic aging is the comparison of oxalate to TOC in the tank waste. Because very little oxalate was originally introduced into the tanks, large quantities of oxalate in current wastes indicate aging. Both oxalate and TOC concentrations were measured in 30 single-shell tanks (SSTs), 14 of which were High Priority tanks. The specific tanks are listed in Table 4-12 of Section 4.3.3.2 of Meacham et al. (1997b) and in Table 3-2. Nine of the 30 tanks had oxalate concentrations that account for more than 75 percent of the TOC in the waste; 13 of the 30 tanks had oxalate concentrations accounting for 25 percent to 75 percent of the TOC; and 8 of the 30 tanks had oxalate concentrations that account for less than 25 percent of the TOC in the waste. Not all degraded TOC produces oxalate. By-products 
other than oxalate also would have been produced from the aging of organic complexants. Therefore, more organics have degraded than indicated in the results. Detailed organic speciation that confirms complexant aging has been completed on five tanks; BY-108, C-106, S-102, SY-101, and SY-103, of which BY-108 and S-102 are High Priority tanks. Speciation results for tanks S-102, SY-101, and SY-103 are reported to Table 4-11 of Section 4.3.3.2 of Meacham et al. (1997b). Tanks S-102, SY-101, and SY-103 were originally organic complexant speciated for the Flammable Gas Safety Program to determine if flammable gas is partially a result of degradation of high-energy organic species. Tanks BY-108 and C-106 were speciated because sample analysis showed the tanks to have high TOC. Speciation results for tank BY-108 are reported in Section 2.2.3 of Speciation of Organic Carbon in Hanford Waste Storage Tanks: Part 1 (Carlson 1997) and speciation results for tank C-106 are reported in Section 2.1.4 of Carlson (1997) and in Section 2.0 of Organic Tanks Safety Program: Advanced Organic Analysis FY 1996 Progress Report (Campbell et al. 1996).

Detailed organic speciation shows that the high energy complexants (EDTA, HEDTA, glycolate, and citrate) have decomposed to lower energy (e.g., ethylenediaminetriacetic acid, iminodiacetic acid [IDA], and nitrilotriacetic acid [NTA]) and low-energy (formate and oxalate) degradation products.

\subsubsection{Organic Complexant Solubility (Question \#3)}

- Does sample analysis confirm that organic complexants are soluble in water?

Water solubility of the organics indicates that saltwell pumping will reduce the risk associated with a tank. If the degree of solubility can be bounded, it will provide guidance for determining the nature of controls required after saltwell pumping.

Sampling and analysis of High Priority and other tanks confirms that organic complexants are soluble in water. Eight High Priority tanks were originally selected to answer the question. Sixty-six tanks actually were used, of which 16 were High Priority tanks to include 3 of the original selections. The additional 63 High Priority or other tanks provided comparable information to that expected from the 5 tanks originally selected but not used.

3.2.2.1 Background. Simulant studies indicate that fuel concentrations in the tanks have been decreased by saltwell pumping. Experiments show that the more reactive organic complexant salts (e.g., NTA, IDA, and EDTA) remain soluble in the tank solutions (Barney 1994), and are removed by saltwell pumping.

Two different simulant solutions were used to conduct experiments to represent a range of compositions found in tank supernatant and interstitial liquids. The experiments were conducted over the temperature range of 25 to $50^{\circ} \mathrm{C}$ to represent standard tank temperatures. The results of these experiments show that the major organic complexants (citrate, EDTA, 
glycolate, and HEDTA) and aging byproducts (acetate, formate, IDA, and NTA) remain soluble even in highly saline solutions. However, the aging byproduct oxalate had a solubility about 100 times lower than other organic complexants. With the exception of oxalate, organic complexants remain in the interstitial liquid and supernatant layers of the tank waste.

3.2.2.2 Sampling and Analysis (See Table 3-2). To confirm organic complexant solubility, tank waste liquid samples from 66 tanks were analyzed for TOC. These include single-shell tanks and double-shell tanks. All samples contained dissolved TOC in concentrations ranging from an average for single-shell tanks of $5.2 \pm 1.1 \mathrm{~g} / \mathrm{L}$ to as much as $40 \mathrm{~g} / \mathrm{L}$ as shown in Appendix F of Meacham et al. (1997b). These concentrations are below saturation points determined in previous experimental work. These results show that organic complexants are in the liquid phase and therefore can be substantially removed from a tank with saltwell pumping.

\subsubsection{Moisture Retention (Question \#6)}

- Does sample analysis establish an authoritative basis for understanding moisture retention in saltcake and in sludge?

Models predicting moisture retention in saltcake and sludge may affect application of safety controls. These models will be evaluated with sample results.

Sampling and analysis results of High Priority and other tanks provide a clear understanding of moisture retention in both sludge and saltcake wastes. Eleven High Priority tanks were originally selected to answer the question. One hundred and three tanks actually were used, of which 21 were High Priority tanks to include all 11 of the original selections. The additional 92 High Priority or other tanks provided supporting information.

3.2.3.1 Background. Two studies of moisture retention phenomena have been conducted: moisture analysis of tank samples and waste surface dryout.

In the first study, a moisture grouping model was used to predict the moisture content in waste tanks. The model categorized tanks into two waste types, saltcake and sludge. These waste types were further categorized into wet and dry groups which were determined both by visual inspection of tank waste contents and review of tank stabilization status records for a tank. By comparing the analytical results of tank waste samples with the moisture grouping model predictions, the moisture retention of a waste matrix before and after saltwell pumping can be evaluated. The moisture grouping model and the tank sample data for weight percent water are compiled in Appendix F of Meacham et al. (1997b).

In the second study, evaluations of actual waste samples were conducted to determine the moisture content of the sample material under various partial pressures of water vapor (Scheele et al. 1996 and 1997). The results are presented in Section 3.2.3.2. 
3.2.3.2 Sampling and Analysis (See Table 3-2). One hundred and three of Hanford's 149 single-shell tanks were evaluated for water retention using moisture analysis of waste samples. The Hanford Site tank characterization database (TCD) contains this verifiable data. Waste from the tanks was grouped into four categories: dry saltcake, dry sludge, wet saltcake; and wet sludge. An evaluation of the data using an analysis of variance (ANOVA) model was performed to find characteristic means for each of these above four categories for surface samples, subsurface samples, and for a combined set of surface and subsurface samples. Details of the ANOVA model are in Appendix F of the organic topical report (Meacham et al. 1997b).

Results of the ANOVA model show that dry saltcake has the lowest characteristic mean of the four categories at approximately $27 \mathrm{wt} \%$ water. The highest mean water content is for wet sludge at approximately $33 \mathrm{wt} \%$ water as shown in Appendix F of Meacham et al. (1997b). Except for wet saltcake, all the waste types had lower mean water values for the surface than for the subsurface.

Because a potential safety hazard is present for tanks that can become unsafe because of high TOC and low water content, tanks that have a high fuel content were studied for the effect of decreases in normal water partial pressures over time. Two tanks, BY-108 (a High Priority tank) and T-111, were sampled and analyzed to determine the extent of waste surface dryout. Tank BY-108 was selected for the waste surface dry out analysis because it was analyzed as containing high TOC. Tank T-111 was selected because it was believed at the time to contain high quantities of complexants. Archive saltcake samples were analyzed from both tanks. The tests performed on these samples consisted of measuring the wt\% water under various partial pressures to determine the concentration of water retained in the surface waste. Results show that the BY-108 surface waste retained from 1 to $16 \mathrm{wt} \%$ water with about $9 \mathrm{wt} \%$ water at the average Hanford partial pressure of 5.5 torr (Scheele et al. 1997). The T-111 surface waste retained from 4 to $44 \mathrm{wt} \%$ water with about $13 \mathrm{wt} \%$ water at the average Hanford partial pressure (Scheele et al. 1996).

The ANOVA model showed that, in most cases, the waste at the surface of the tank is dryer than the waste at lower depths. The waste dry out analysis showed that, for the two tanks investigated, waste material is capable of drying out when exposed to ambient air. Sampling analysis has been shown to provide a clear understanding of moisture retention in the waste.

\subsubsection{Energetics/Moisture Criteria (Question \#8)}

- Does the sample analysis confirm the postulated energetics and moisture criteria for propagation of fuel/oxidizer reactions?

Confirming the postulated energetics and moisture criteria would allow revising the safety screening criteria. 
Sampling and analysis results of high-organic complexant waste tanks confirms that postulated energetics and moisture safety criteria are applicable for real waste conditions. Six High Priority tanks were originally selected to answer the question. Twelve tanks actually were used, of which six were High Priority tanks to include two of the original selections. The additional ten High Priority or other tanks provided comparable information to that expected from the four tanks originally selected but not used.

3.2.4.1 Background. Safe storage criteria given in Section 1.2 of Webb et al. (1995) have been established through theoretical analysis and tests on waste surrogates. The minimum fuel concentration required to support a propagating reaction has been determined using a contact-temperature ignition model (Fauske et al. 1995). A necessary (but not sufficient) condition for a propagating reaction is that the fuel concentration be greater than $1,200 \mathrm{~J} / \mathrm{g}$ (4.5 wt\% TOC), on an energy equivalent basis as shown in Section 4.2 of Fauske et al. (1995).

For fuel concentrations between 1,200 and $2,100 \mathrm{~J} / \mathrm{g}$, the waste moisture (free water) content required to prevent a propagating reaction varies linearly from 0 to $20 \mathrm{wt} \%$. Above $20 \mathrm{wt} \%$, the fuel-moisture linear relationship no longer holds because the mixture becomes liquid continuous and a stoichiometric fuel-oxidizer mixture reaction will not propagate (Fauske et al. 1995).

The theoretical fuel/moisture criterion was tested on waste simulants using two different analytical instruments; the reactive system screening tool (RSST) and tube propagation. The RSST method tested for propagation by heating dry simulant samples at a constant rate to observe change in the self-heating rate. No samples with a dry weight fuel of $4.5 \mathrm{wt} \% \mathrm{TOC}$ or less propagated. The tube propagation instrument tested for propagation by igniting waste in one end of a thin, insulated stainless-steel cylinder to determine if the reaction continued through the rest of the waste. The test was performed on dry and wet waste simulants. All the simulant mixtures that propagated were over the theoretical fuel/moisture criterion.

3.2.4.2 Sampling and Analysis (See Table 3-2). Tests were performed to compare the postulated fuel/moisture criterion with measurements obtained from actual waste samples as shown in Table 4-7 of Section 4.3.2.1 and in Appendix F of Meacham et al. (1997b). The waste samples selected for testing had TOC concentrations exceeding $3.0 \mathrm{wt} \%$ (the original organic Watch List criterion) or differential scanning calorimetry results greater than $480 \mathrm{~J} / \mathrm{g}$, the safety screening criterion shown in Table 6.1 of Section 6.0 in Dukelow et al. (1995). Tank samples tested by the RSST were from tanks AN-107, AW-101, BY-104, BY-105, BY-108, C-201, C-204, U-102, U-106, and U-111. Tanks U-105, U-106, and C-104 were tested using the tube propagation method. Of the tanks tested by the RSST, tanks AW-101, BY-104, BY-105, BY-108, C-104, and U-105 were High Priority tanks. The fuel energy criterion developed theoretically and by simulant testing was confirmed. 


\subsubsection{Sampling and Analysis Summary for Organic Complexant Questions}

Table 3-2 summarizes the sampling and analysis performed for the organic complexant questions. The first column of Table 3-2 lists the tanks that were originally intended to be used for the organic complexant questions, plus other tanks that were actually used. High Priority tanks are denoted with an " $\mathrm{X}$ " in the second column. The sampling status of tanks is shown in the third column. The remaining columns depict which tanks were used for the four questions within the organic complexant issue, and more specifically, the analyses used for each question. Gray shading indicates that, in Appendix F of Recommendation 93-5

Implementation Plan (DOE-RL 1996), a tank was originally intended in to be used to address a particular question. The table cells indicate whether or not a tank was "Used" to address a question. 


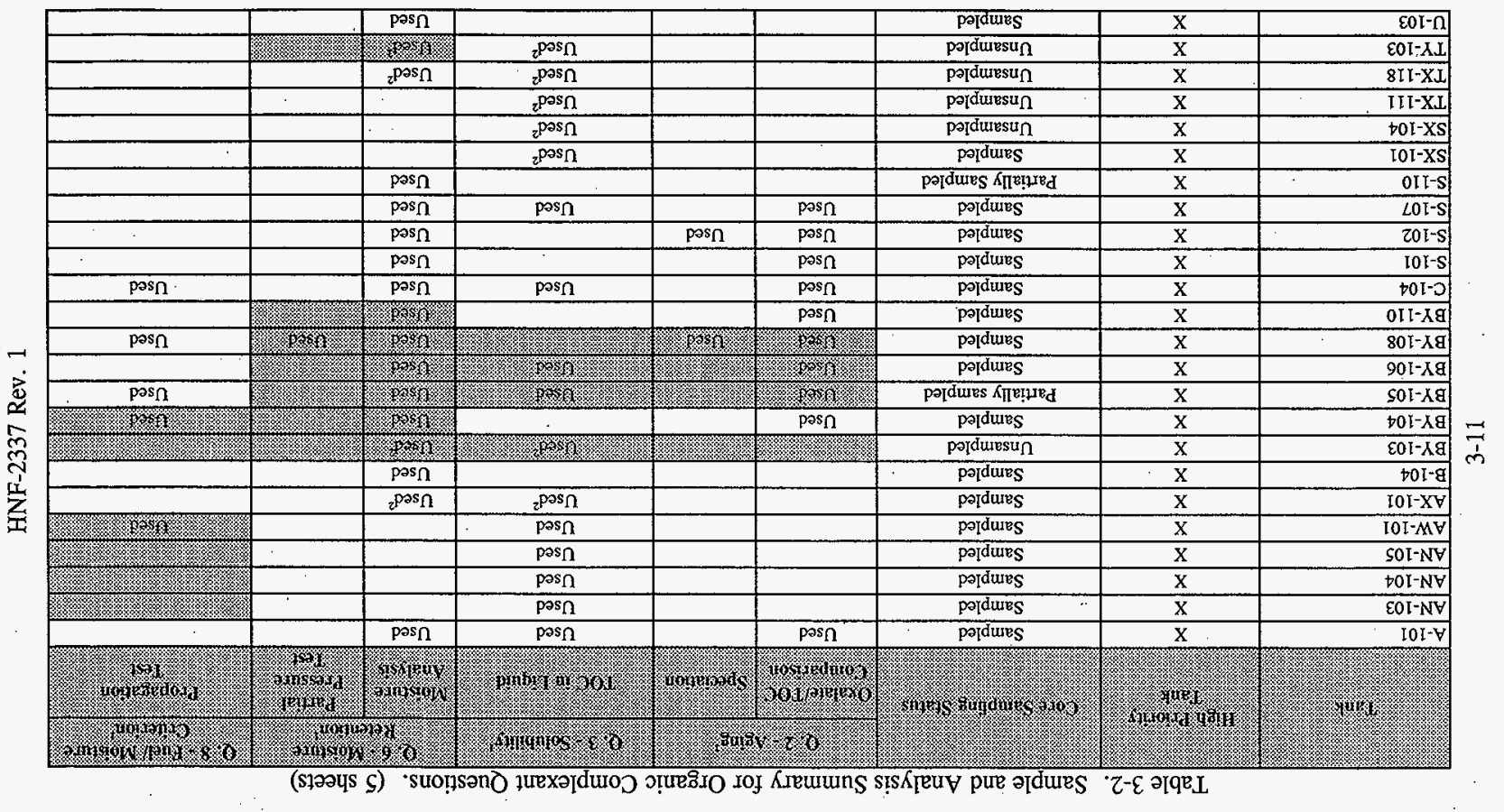


Table 3-2. Sample and Analysis Summary for Organic Complexant Questions. (5 sheets)

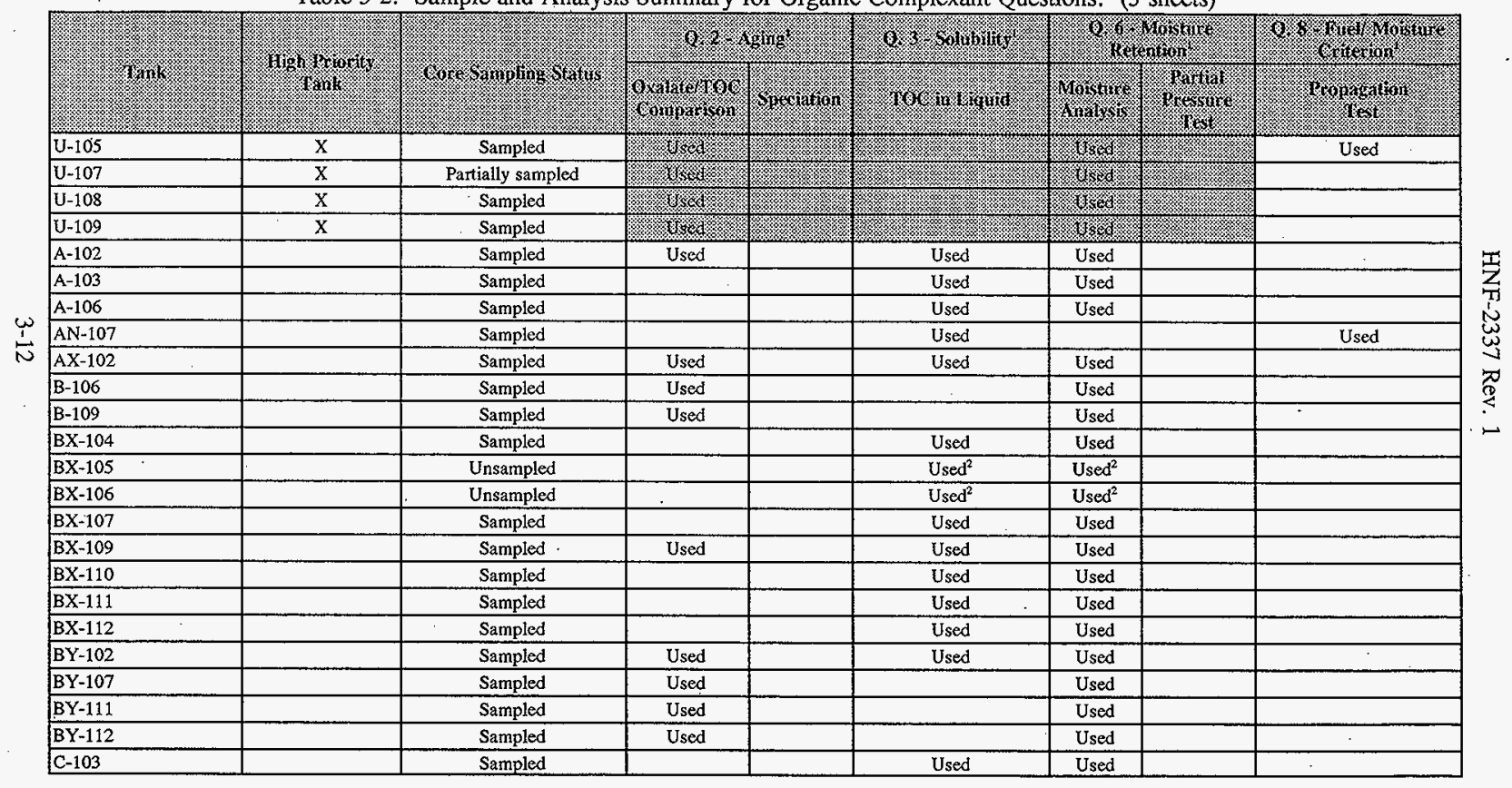


HNF-2337 Rev. 1

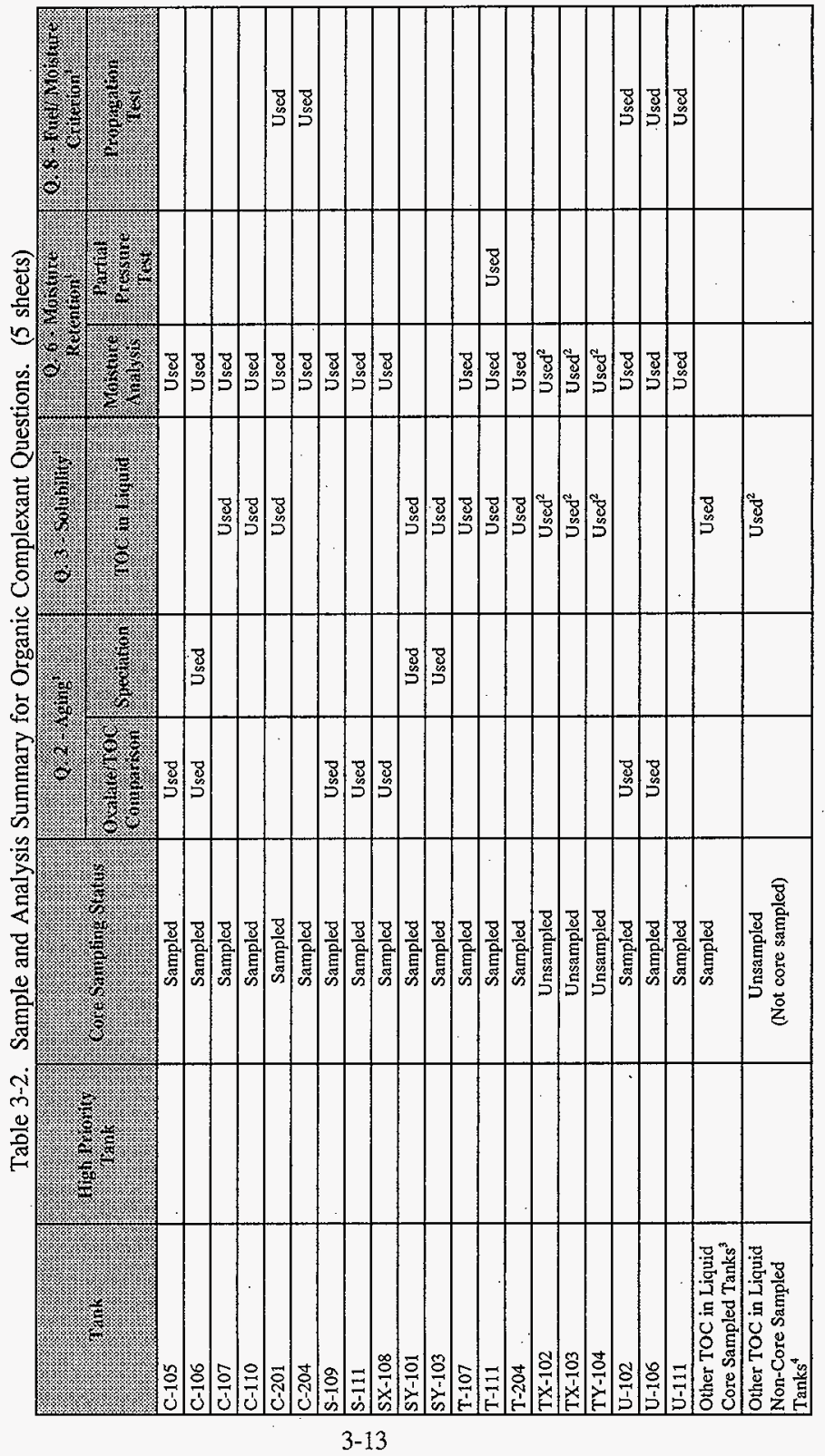




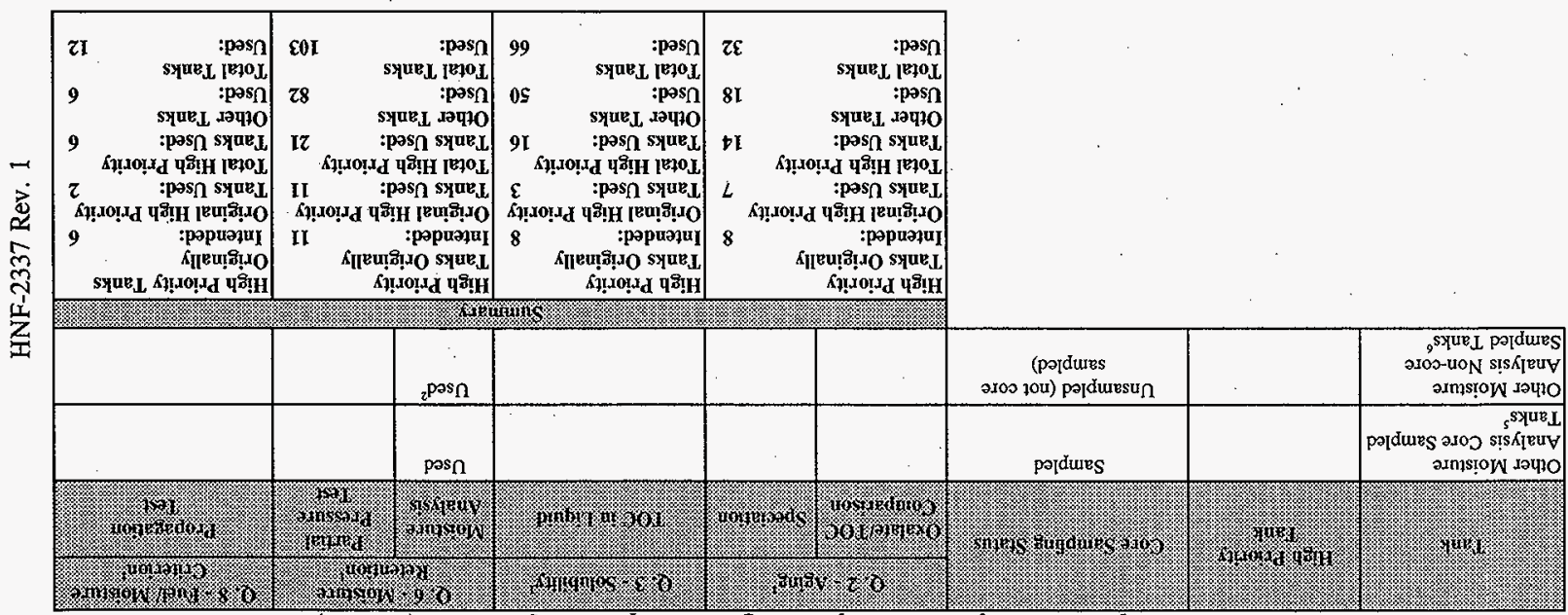

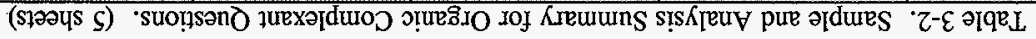




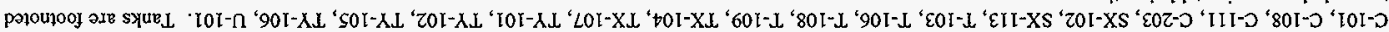

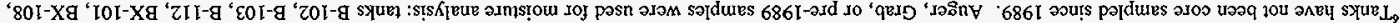

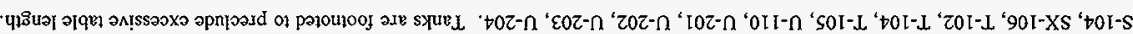

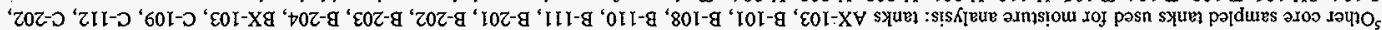

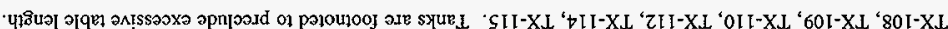

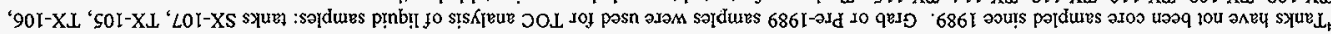

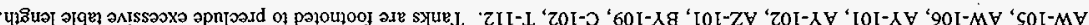
'十0I-MV 'COI-MV ‘

6861

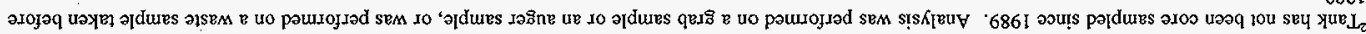

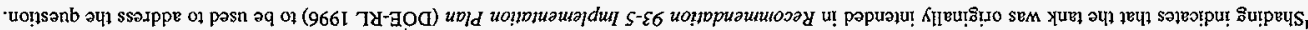

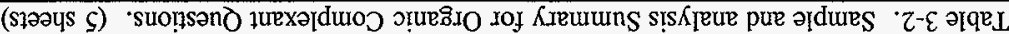




\subsection{ORGANIC SOLVENT SAFETY ISSUE}

Given a sufficient ignition source, there are two potential hazards associated with organic solvents: an organic solvent pool fire; and ignition of organic solvent that is entrained in waste solids (a wick fire). Organic solvents used in the nuclear material separation process are difficult to ignite. Sparks, impacts, shocks, and friction sources lack sufficient energy to ignite organic solvent pool fires. The credible ignition sources have been narrowed to robust and/or sustained energy sources such as lightning strikes or gasoline fires (resulting from vehicle gasoline tank ruptures).

Because presence of organic solvent vapors in a tank headspace shows that organic solvents must be in the condensed phase, vapor sampling has proven to be an effective method for identifying organic solvent tanks.

Characterization for the organic solvent safety issue has matured since the safety analysis on C-103 (Postma et al. 1994) was completed. The original accident scenario assumed catastrophic failure of the tank dome during an organic solvent burn if a SST did not have an adequate vent path. Failure of the dome led to radiological consequences above risk evaluation guidelines. Preliminary calculations showed that the solvent pool area would have to be larger than one square meter $\left(\mathrm{m}^{2}\right)$ to create enough pressure to collapse the tank dome. Thus, the original approach required identification of tanks containing significant quantities (i.e., greater than a $1 \mathrm{~m}^{2}$ pool) of organic solvent and ensuring an adequate vent path in those tanks that contain significant organic solvent.

Tank structural integrity was reexamined in 1996 as part of the Authorization Basis upgrade (Noorani 1997). Analyses in Section 5.3.2.15 of Noorani (1997) and in Section 5.3.2 of Han (1996) showed that the tank dome would not fail catastrophically under the pressures developed during an organic solvent fire. Instead, the dome would develop cracks and fissures to release the internal pressure and stay intact. Later analyses found in Section 1.0 of Cowley (1997) and in Section 6.2 of Cowley and Postma (1996) showed radiological consequences to be within risk evaluation guidelines for passively ventilated tanks. Ensuring an adequate vent path was rendered insignificant by the tank structural integrity analysis.

Although radiological consequences fell within guidelines, toxicological consequences still exceeded risk evaluation guidelines as documented in Section 1.0 of the Cowley (1997) report. Recently, the effects of jet mixing and aerosol depletion were included in toxicological consequence calculations. The revised consequence calculations showed that the solvent fire hazard falls below risk evaluation guidelines when controls are applied. This is true even if all tanks were assumed to contain organic solvent.

Sections 3.3.1 and 3.3.2 address vapor and condensed phase sampling and analysis related to questions \#4 and \#5, respectively. Both questions address "location" of organic solvent in the condensed phase. Because of the similarity of the two questions, they should be considered together. For condensed phase results, the same tanks were used for question \#4 that were used for question $\# 5$. 


\subsubsection{Relationship of Organic Solvents in Vapor and Solid/Liquid Phases (Question \#4)}

- Does detection of organic solvents in the vapor phase correspond to presence of the solvents in the liquid or solid phases?

Vapor sampling may be used as an indicator of condensed-phase solvents. Vapor sampling results may indicate the need for specific controls or actions without requiring a core sample. The comparison studies on the High Priority tanks can reduce the number of false positives by confirming the relationship between vapor space concentration and condensed-phase concentration.

Sampling and analysis with comparison of vapor samples and core samples confirms that detection of solvents in the vapor phase corresponds to the presence of solvents in the condensed (solid/liquid) phases of a tank. Three High Priority tanks were originally selected to answer the question. Four tanks actually were used, of which two were High Priority tanks and original selections. The additional two other tanks provided comparable information to that expected from the one tank originally selected but not used.

3.3.1.1 Background. Because vapor sampling is the sampling of choice for solvent screening, it was necessary to show that solvents detected in the vapor correspond to solvents detected in the condensed portion of the tank.

3.3.1.2 Sampling and Analysis (See Table 3-3). To show a correlation between vapor and condensed phase organic solvents, organic speciation of both vapor and core samples were required. Four tanks were used to test correlation. Tanks BY-108 (a High Priority tank), $\mathrm{C}-102$, and $\mathrm{C}-103$ were identified through vapor sampling as three tanks calculated to have more than a $1 \mathrm{~m}^{2}$ pool of organic solvent in the waste. These tanks and tank BY-110 (a High Priority tank, and calculated to have less than $1 \mathrm{~m}^{2}$ of solvent pool), were speciated to determine which solvents are present in the condensed waste for each tank. Speciation results of core samples for BY-108 and BY-110, and auger samples for C-102 are reported in Comparison of Organic Constituents Found in the Condensed and Vapor Phases of Tanks 241-BY-108, 241-BY-110 and 241-C-102 (Huckaby et al. 1996). Speciation for tank C-103 is recorded in Waste Tank Organic Safety Project Analysis of Liquid Samples from Hanford Waste Tank 241-C-103 (Pool and Bean 1994).

Earlier process streams contained normal paraffin hydrocarbon (NPH) solvents. The Organic Safety Program expected to find some of these solvents in the Hanford Site 200 Area tanks. Characterization data (Huckaby et al. 1996) have confirmed that a number of hydrocarbon species present in NPH solvents (i.e., dodecane, tridecane, and tetradecane) are present in tank headspaces.

Differences between the measured headspace organic vapor concentrations and the organic vapor concentrations estimated from condensed phase data for tanks BY-108, BY-110 and C-102 show that the tank headspaces are not in equilibrium with the organic solvent detected 
in the condensed waste. This is reasonable because passive ventilation of a tank prevents establishment of equilibrium between the vapor and condensed phases. However, this also shows that specific concentrations in the vapor phase cannot be reliably applied to specific concentrations in the condensed phase. It shows only that if in the vapor phase, organic solvents are present in the condensed phase.

Condensed phase samples from BY-108 showed no solvents in the top $50 \mathrm{~cm}$ of waste as shown in Section 2.1 of Campbell et al. (1995) and Section 5.2 of Baldwin et al. (1996). However, samples below $50 \mathrm{~cm}$ showed NPH and some tributyl phosphate (TBP). The condensed phase solvents are detected by vapor analysis, but not their location within the tank. (See question \#5.)

Semivolatile NPHs and TBP were identified in core and auger samples from tanks BY-108 and $\mathrm{C}-102$. Headspace vapor samples from these tanks also show NPHs and TBP. Although some semi volatile NPHs were observed in tank BY-110 headspace samples, condensed phase samples showed no measurable NPHs. This was consistent with the less than $1 \mathrm{~m}^{2}$ solvent pool calculated for BY-110.

The floating organic layer samples from tank C-103 consisted of both NPH and TBP. Branched alkanes and dibutyl butylphosphonate (DBBP) were also found in lesser quantities. In the aqueous layer, TBP, DBBP, and NPH were found at the $\mu \mathrm{g} / \mathrm{mL}$ level as shown in Section 2.2.1 of Pool and Bean (1994). These compounds also were observed in the vapor phase as was to be expected from a floating layer.

The conclusion from the comparison of vapor and condensed-phase sample data is that headspace vapor sampling detects the presence of organic solvent even if the solvent is entrained in the waste.

\subsubsection{Location of Organic Solvents (Question \#5)}

- Does sample analysis confirm the anticipated locations of organic solvents within the liquid and solid waste (surface layers, interfaces, entrained)?

Location of the organic solvents affects the hazard. The correct controls can be selected to match the consequence associated with the solvent distribution.

Vapor sampling is able to detect the presence of organic solvents in the condensed phase of tank waste, but is not able to detect the exact location of the solvents. Condensed phase sampling, however, does detect organic solvent depth locations. Eight High Priority tanks were originally selected to answer the question. Eighty-two tanks actually were used, of which 20 were High Priority tanks to include all 8 of the original selections. The additional 74 High Priority or other tanks provided supporting information. 
3.3.2.1 Background. Historical records and models of process streams provide insight on the location of organic solvents in the waste tanks. The $\mathrm{C}$ tank farm has directly received Plutonium Uranium Extraction (PUREX) plant organic waste as shown in Section 1.1 of Sederburg and Reddick (1994). This waste contained the extractant TBP in a solution of semivolatile diluents. Different diluent mixtures were used during the 16 year life of the PUREX process, but for chemical inertness, semivolatile NPHs were the most commonly used. Much of the waste containing TBP and diluents was transferred to the BY tank farm in the late 1950s and early 1960s as recorded in Section 1.0 of Huckaby et al. (1996). Many other processes and transfers occurred at the Hanford Site, and compositions of tank waste have been modeled from transfer records, waste stream compositions, and solubility data.

Because records of waste stream composition and waste transfers may not be always reliable, limited core and extensive vapor sampling was performed to determine if it is possible to specifically identify the location of organic solvents in the tank waste.

3.3.2.2 Sampling and Analysis (See Table 3-3). Eighty-two of the 149 SSTs have been vapor screened including all of the tanks in BY tank farm and 12 of the 16 tanks in $C$ tank farm. These tanks were chosen based on waste transfers of PUREX organic wash waste as given in Section 3.1.4 of Cowley (1997) and in Agnew (1996). Of these, 13 had headspace vapor concentrations corresponding to an organic liquid surface area greater than $1 \mathrm{~m}^{2}$. Forty-eight tanks do not contain significant amounts (greater than $1 \mathrm{~m}^{2}$ ) of organic liquid waste (Huckaby and Sklarew 1997). Twenty-one tanks could not be categorized as greater or less than $1 \mathrm{~m}^{2}$ within confidence limits. Vapor sampling identified tanks worthy of condensed phase sampling.

Semivolatile analyses were obtained for condensed phase samples of tanks BY-108, BY-110 (both High Priority tanks), C-102, C-103, and C-204 to determine presence and location of organic species in the waste. Samples from tanks C-102, C-103, and C-204 show that the organic species are on top of or in the first segment of the waste. For tank BY-110, less than a $1 \mathrm{~m}^{2}$ organic pool was expected from vapor sampling and no detectable semivolatile organics were found in the waste.

Vapor and condensed-phase sample data comparison for BY-108 shows that headspace vapor sampling detected the presence of organic solvent, even though no solvent was found in the top $50 \mathrm{~cm}$ of the waste. However, sample segments below $50 \mathrm{~cm}$ showed NPH and some TBP.

Vapor sampling detects solvents on the surface and entrained in the waste. There is no indication from the sampling performed that vapor samples can be used to predict the exact location of organic solvent in the condensed phase. However, condensed phase sampling does detect solvent depth locations. 


\subsubsection{Representativeness of Tank 241-C-103 Solvents to Other Tanks (Question \#9)}

- Does the sample analysis confirm that the solvents found in tank $\mathrm{C}-103$ are representative of solvents found in other tanks?

Confirming solvent similarity would allow refinement of the screening criteria to determine if organic solvents were present.

A comparison of the solvent in the vapor and condensed phases of tank C-103 with other selected tanks shows that tank $\mathrm{C}-103$ is a bounding tank and is representative of organic solvents found in other tanks. Two High Priority tanks were originally selected to answer the question. Five tanks actually were used, of which two were High Priority tanks and original selections. The additional three other tanks provided supporting information.

3.3.3.1 Background. Tank C-103 contains the highest concentration of organic solvents in the vapor phase of any SST vapor sampled. It also is expected to contain more flammable solvents on a volume basis than any other tank on the Hanford Site.

3.3.3.2 Sampling and Analysis (See Table 3-3). Vapor and condensed waste solvent analysis results for tanks C-103, BY-108, BY-110, C-102, and C-204 are compiled in the letter, Comparison of the Composition of Organic Solvents in Tank 241-C-103 to Tanks 241-BY-108, 241-BY-110, 241-C-102, and 241-C-204 (Fergestrom 1998). Tanks BY-108, BY-110, C-102, and $\mathrm{C}-204$ were selected for the comparision because organic speciation of solid samples was performed on these tanks. Speciation was performed because the tanks tested positive for solvents in the vapor sampling. Sixty percent of the condensed and vapor-phase solvent components found in C-103 also are quantitatively detected in the other four tanks evaluated. Comparison of the five highest concentration semivolatile constituents in the vapor and condensed phase in the five tanks shows a complete overlap between the constituents identified in tank C-103 and constituents in at least one of the other four tanks. Based on inflammability range information, all the constituents detected in the other four tanks in both the vapor and condensed phases but not in $\mathrm{C}-103$, are below their respective inflammability ranges. The inflammability range is the range of concentration, over which a compound in its gaseous form is flammable.

Comparison of the sampling results for tank $\mathrm{C}-103$ to four other tanks shows $\mathrm{C}-103$ to be a bounding tank because it has higher concentrations of flammable solvents than the other tanks. This further supports the conclusion that tank $\mathrm{C}-103$ is a bounding tank as stated in Babad (1996).

\subsubsection{Sampling and Analysis Summary for Organic Solvent Questions}

Table 3-3 below summarizes the sampling and analysis performed for the organic solvent questions. The first column of Table 3-3 lists the tanks that were originally intended to be used for the organic solvent questions plus other tanks that actually were used. High Priority 
tanks are denoted with an " $\mathrm{X}$ " in the second column. The sampling status of tanks is shown in the third column. The remaining columns depict which tanks were used for the three questions within the organic solvent issue. Gray shading indicates that, in Appendix F of

Recommendation 93-5 Implementation Plan (DOE-RL, 1996), a tank was originally intended to be used to help address a particular question. The table cells indicate whether or not a tank was "Used" to address a question. 


\begin{tabular}{|c|c|c|c|c|c|}
\hline pas & pasn & & pardurs & & ${ }_{5}+02-0$ \\
\hline pos $\Omega$ & $\operatorname{pos} \Omega$ & $\operatorname{pas} \Omega$ & pordurs & & ${ }_{s} \mathrm{EOI}-\mathrm{O}$ \\
\hline \multirow[t]{13}{*}{ pas $\Omega$} & pasn & pas $\Omega$ & pordurs & & $s^{2} 201-2$ \\
\hline & 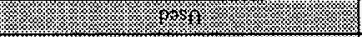 & & poldures & $\mathrm{x}$ & $60 \mathrm{r}-\mathrm{n}$ \\
\hline & 1) & & poidures & $\mathrm{X}$ & $80 \mathrm{I}-\mathrm{n}$ \\
\hline & 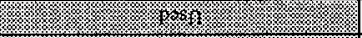 & & pordures & $\mathrm{X}$ & $\varepsilon L O I-n$ \\
\hline & $\sqrt{3}$ & & pordures & $\mathrm{x}$ & SOI-n \\
\hline & posn & & popdurs & $\mathrm{X}$ & Eo[-n \\
\hline & pasn & & pajdurs & $\mathrm{X}$ & $\varepsilon_{0} I-X I$ \\
\hline & posn & & paydures & $x$ & $81 I-X x$ \\
\hline & $\operatorname{pas} \Omega$ & & pojdures & $\mathrm{x}$ & III-XI \\
\hline & pasn & & peidurs & $\mathrm{x}$ & oI I-S \\
\hline & $\operatorname{pas} \Omega$ & & pe|dues & $\mathrm{X}$ & LOI-S \\
\hline & $p \rho s n$ & & poldures & $x$ & $20 \mathrm{I}-\mathrm{s}$ \\
\hline & $\operatorname{pos} n$ & & poldures & $\mathrm{X}$ & LOI-S \\
\hline (6) & $\operatorname{pos} n$ & (6.) & paidures & $\mathrm{X}$ & $\varsigma^{0 I I-\lambda \mathrm{g}}$ \\
\hline W & r. & (2) & perdurs & $\mathrm{X}$ & $s 80 I-\lambda \mathrm{a}$ \\
\hline & 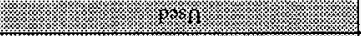 & & perdurs & $\mathrm{X}$ & $90 \mathrm{t}-\lambda \mathrm{g}$ \\
\hline & 26-2/ & & poidures & $\mathrm{X}$ & $\varepsilon 0 I-\lambda \mathrm{g}$ \\
\hline & posn & & poldures & $\mathrm{x}$ & toI-Xg \\
\hline & (1) & 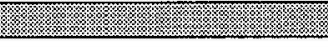 & peidures & $\mathrm{x}$ & $\varepsilon_{\varepsilon} \varepsilon 01-\lambda \mathrm{g}$ \\
\hline & posn & & paidures & $\mathrm{x}$ & $\mathrm{IOI}-\mathrm{XV}$ \\
\hline & pasn & & poidures & $\mathrm{x}$ & $10 I-7$ \\
\hline (7) & 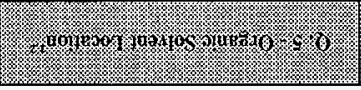 & (1918) & 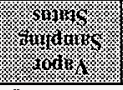 & (3) & 110.8. \\
\hline
\end{tabular}




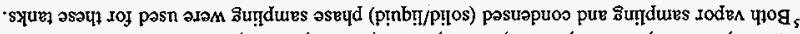

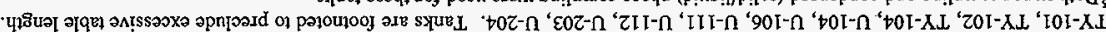

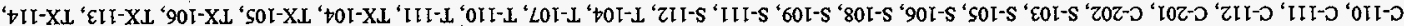

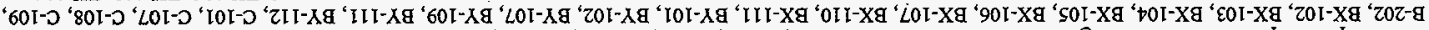

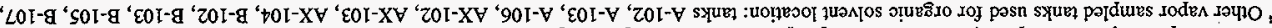

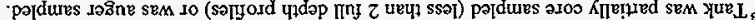

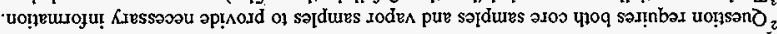

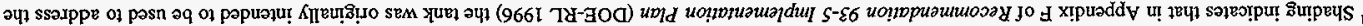

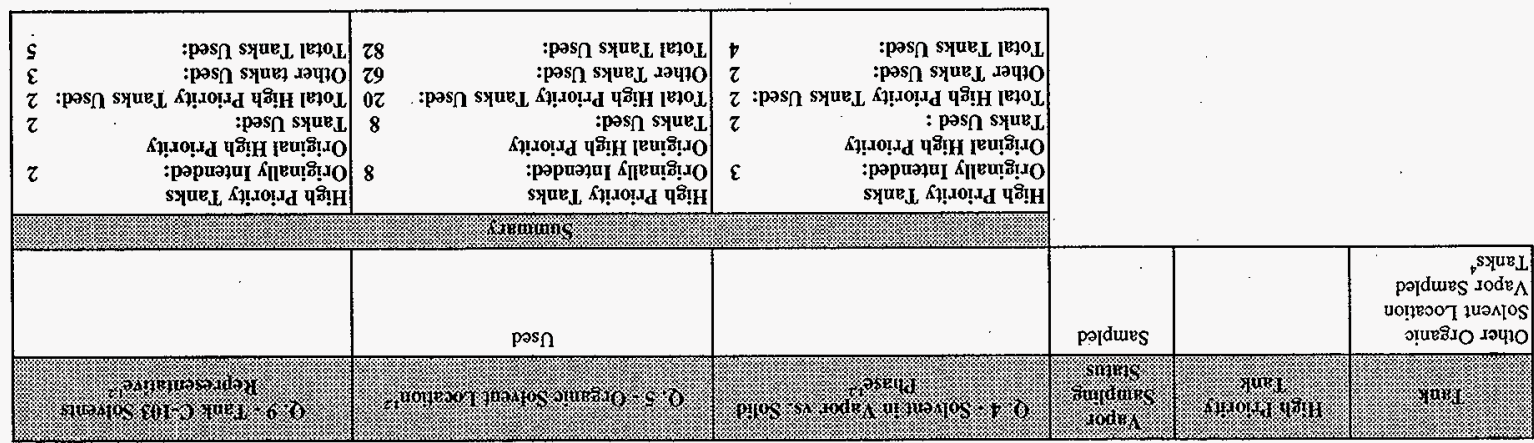

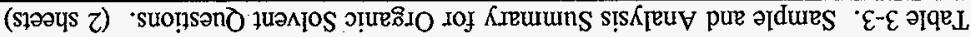




\subsection{FLAMMABLE GAS SAFETY ISSUE}

Radiolytic and chemical decomposition reactions occurring in tank waste produce flammable gases (principally hydrogen and ammonia), an oxidizer (nitrous oxide), and an inert gas (nitrogen). The hazard is related to two phenomena: slow, steady accumulation of flammable gases in the tank headspace and episodic releases of flammable gases at comparatively high rates and concentrations. Sampling and analysis of the flammable gas tanks listed in Appendix F of Recommendation 93-5 Implementation Plan (DOE-RL 1996) was performed to better understand the phenomenon of flammable gas retention.

\subsubsection{Flammable Gas Retention (Question \#7)}

- Does sample analysis provide a basis for determining the amount and composition of retained gases in the bounding flammable gas tanks?

The bounding flammable gas tanks represent the worst conditions that must be controlled or mitigated. Specifying the correct action based on the results from these tanks ensures that all other flammable gas retaining tanks are conservatively controlled.

The retained gas sampler (RGS) has been demonstrated to be an effective sampling tool for determining the amount and composition of retained gases in flammable gas tanks. Five High Priority tanks were originally selected to answer the question. Nine tanks actually were used, of which six were High Priority Tanks to include all five of the original selections. The additional four High Priority or other tanks provided supporting information.

3.4.1.1 Background. Radiolysis of water and thermolytic decomposition of organic material generates flammable gases. In most waste tanks, flammable gas is released to the tank head space at about the same rate as it is generated. The generation rate is so low compared with passive or active ventilation flow rates, that the flammable gas is diluted far below the concentration necessary for ignition. However, some tanks show evidence that they retain significant volumes of flammable gas in the waste. Gas retained in these tanks can be released as a spontaneous or induced gas release event that can significantly increase the flammable gas concentration in the tank headspace. Because water content, complex chemical reactions, radiation, and physical conditions for storing waste vary, gas retention in tanks is expected to vary.

Recommendation 93-5 Implementation Plan lists five High Priority tanks as bounding tanks for the evaluation of the retained gas sampling method: tanks A-101, AN-103, AN-104, AN-105, and AW-101. Tanks AN-103, AN-104, AN-105, and AW-101 are double-shell flammable gas tanks. These tanks were selected for study because they were expected to contain the most significant volumes of retained gasses. Tank A-101 is a single-shell tank that was determined in Tables 2-1 and 2-4 of Section 2.0 and in Section 3.1 of Evaluation of Hanford Tanks for Trapped Gas (Hodgson et al. 1996) to produce high quantities of flammable gas. 
3.4.1.2 Sampling and Analysis (See Table 3-4). To determine the quantity and composition of gases stored in the Hanford Site waste tanks, the retained gas sampler (RGS) was developed. By using the RGS, a direct measurement of the amount and composition of gas retained in the tanks can be obtained through core sampling. The five bounding flammable gas tanks listed earlier and other tanks listed later in this section were sampled with the RGS. Composition and Quantities of Retained Gas Measured in Hanford Waste Tanks 241-AW-101, $A-101, A N-105, A N-104$, and $A N-103$ (Shekarriz et al. 1997) summarizes the gas concentrations, void fraction, and estimated hydrogen volume of the five bounding High Priority tanks.

To confirm the gas volume measurements obtained from RGS samples, tank void fraction as determined from RGS samples were compared to tank void fractions measured by a void fraction instrument (VFI) in Section 3.0 of Meyer et al. (1997). For the bounding tanks listed above, with the exception of A-101, the void fraction versus waste depth was plotted for the RGS void fraction and the VFI void fraction. The results of this comparison show that the void fraction results from the RGS and VFI methods are consistent (Shekarriz et al. 1997) and provides credibility to the RGS results.

In addition to the bounding flammable gas tanks listed in Appendix F of Recommendation 93-5 Implementation Plan (DOE-RL 1996), tanks U-103, S-106, BY-101, and BY-109 have also been sampled with the RGS (Mahoney et al. 1997). Tank U-103 is a High Priority tank that was added to the High Priority list after the implementation plan was released as found in Section 3.4 of the attachment to Wagoner (1997) (see Table 2-1 footnote).

\subsubsection{Sampling and Analysis Summary for Flammable Gas Question}

Table 3-4 summarizes the sampling and analysis performed for the flammable gas question. The first column of Table 3-4 lists the tanks originally intended to be used for the flammable gas question plus other tanks that actually were used. High Priority tanks are denoted by an " $\mathrm{X}$ " in the second column. The sampling status of the tanks is shown in the third column. The remaining columns depict the tanks used for the flammable gas question. Gray shading indicates that, in Appendix F of Recommendation 93-5 Implementation Plan (DOE-RL 1996), a tank was originally intended to be used to address the question. The table cells indicate whether or not a tank was "Used" to address the question. 
Table 3-4. Sample and Analysis Summary for Flammable Gas Question.

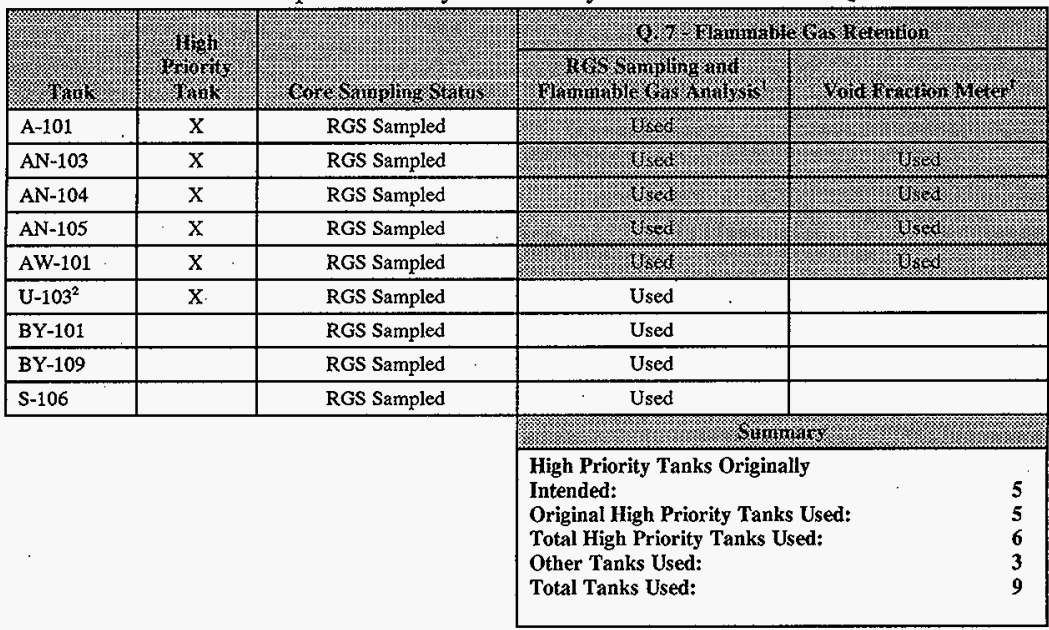

Notes:
${ }^{1}$ Shading indicates that, in Appendix F of Recommendation 93-5 Implementation Plan (DOE-RL 1996), the tank was originally intended to be used to address the question.
${ }^{2}$ Tank U-103 was added to the High Priority list after the 93-5 Implementation Plan was issued (Section 3.4 of the attachment to Wagoner [1997]).

\subsection{DISPOSAL PLANNING ISSUES}

When Recommendation 93-5 Implementation Plan (DOE-RL 1996) was issued, the characterization focus for disposal (retrieval, treatment, and immobilization) programs was to establish waste type groupings and to determine a priority of tanks for sampling. The intent of the tank grouping effort was to study process behaviors on bounding waste type groups to determine which groups of waste would be the most difficult to process and then to develop process designs based upon these limiting groups (question \#12). Another focus was to determine the variability of waste within tanks. Question $\# 10$ addressed within-tank variability. Question \#11 addressed variability between saltcake types.

Since the issue of Recommendation 93-5 Implementation Plan (DOE-RL 1996), disposal planning has changed. Waste disposal plans have been developed in two phases. Phase I plans for staging (retrieval and treatment) of low-activity waste (LAW) feed, staging of limited ámounts of high-level waste (HLW) feed, and receipt of various final and intermediate waste 
products from the immobilization processes. Phase II plans for retrieval, treatment, and immobilization of waste remaining in tank farms after Phase I.

The disposal planning process has been developed in Level I Logic. Future characterization requirements for Phases I and II of the disposal effort will be determined from the data quality objectives process and documented in problem-specific DQOs developed to support completion of activities contained in the logic. Specific characterization activities in support of DQOs will be developed through the Tank Characterization Technical Sampling Basis (Brown et al. 1997) and the Waste Information Requirements Document (Winkelman et al. 1997) as revised annually.

Sampling and analysis for disposal planning questions has been completed with much more sampling effort than was originally intended. Sampling summary is discussed in the following sections.

\subsubsection{Spatial Variability (Question \#10)}

- What is the degree of spatial variability and level of resolution observed in a highly variable tank and in a homogenous tank?

These observations provide additional guidance on the number of samples that may be required to bound specific problems through sample analysis.

Spatial variability information does not support Phase I and II planning efforts and is no longer needed to support near-term planning for disposal programs. Eighteen High Priority tanks were originally selected to address the question. Fifty-six tanks actually were sampled and analyzed, of which 14 were High Priority tanks to include 11 of the original selections. The additional 45 High Priority or other tanks provide comparable information to that expected from the 7 tanks originally selected but not used.

3.5.1.1 Background. Spatial variability is the change in waste composition within the tanks as a function of position. Because of the way tanks were initially filled, waste management practices in the tank farms, and physical principles governing fluid flow and particle settling behavior, the contents of some tanks vary as a function of the waste's horizontal and/or vertical position. Information regarding the processing history of a tank can indicate whether a tank is expected to have a large degree of spatial variability. In general, tanks that received waste from several different sources have a higher likelihood of being spatially variable because of flow behavior and the lack of mixing in the tanks. Sampling information can be used to statistically quantify the spatial variability.

3.5.1.2 Sampling and Analysis (See Table 3-5). Sampling and analysis to address the question was completed for the 56 tanks listed in Table 3-5. Quantitative estimates of spatial variability have been computed for these tanks. Work to address question \#10 through further statistical evaluation will not be conducted. Spatial variability information does not support Phase I 
planning because 1) the mobilization and retrieval methods planned for Phase I tanks are expected to homogenize the waste, and 2) the plans for feed delivery of the waste include the ability to blend waste from multiple tanks to meet contract limits. Likewise, the current planning for Phase II activities does not require spatial variability information.

\subsubsection{Saltcake Variability (Question \#11)}

- What is the range of compositional variability observed in saltcake? For disposal purposes, can all saltcakes be treated as similar, or are there important differences among saltcakes resulting from different processes?

Saltcake variability information does not support Phase I and II planning efforts and is no longer needed to support disposal programs. Fifteen High Priority tanks were originally selected to address the question. Thirty-four tanks actually were sampled and analyzed, of which 15 were High Priority tanks to include 7 of the original selections. The additional 27 High Priority or other tanks provided comparable information to that expected from the 8 tanks originally selected but not used.

3.5.2.1 Background. Variability in saltcake is a particular example of compositional variation in the waste. Three primary separation processes were used at the Hanford Site to separate plutonium from irradiated fuel rods. In addition, several subsequent efforts were conducted to remove fission products from the waste and to reduce waste volume. Each separation process used different solvents and processing chemicals. Different methods of evaporation were used throughout the volume reduction processes. Saltcakes are the byproduct of waste reduction efforts by evaporation. Sampling information can be used to estimate the variability among saltcake types.

\subsubsection{Sampling and Analysis (See Table 3-5). Thirty-four tanks containing large} quantities of saltcake were sampled and analyzed on both the segment and composite level with descriptive statistics generated for both data sets. These tanks were expected to contain all saltcake or to have a layer of saltcake over 50,000 gallons as predicted by the tank layering model reported in Appendix $\mathrm{C}$ of Hanford Tank Chemical and Radionuclide Inventories: HDW Model Rev. 4 (Agnew 1997). The tanks are listed in Table 3-5. Work to answer question \#11 through further statistical evaluation will not be conducted. Section 2.1 of TWRS Operation and Utilization Plan (Kirkbride et al. 1997) summarizes the current tank retrieval sequence operating scenario for the retrieval and treatment of all SST and DST waste remaining after the completion of Phase $\mathrm{I}$. The process simulation model used to generate the operating scenario does not require information for saltcake variability.

\subsubsection{Predictive Reliability of Process Models (Question \#12)}

- How well do the models of the key waste type compositions compare with the observed concentrations? 
The composition estimates and the variability in composition within a key waste type determine whether wastes can be grouped and treated as similar with regard to any specific issue. Compositional variability determines the number of tanks that must be sampled to ensure that waste processing decisions address the majority of the waste. If composition and variability of waste types can be quantified, certain decisions may be made on specific tanks based on historical records and samples from related tanks without sampling each individual tank. The five primary waste types addressed in single-shell tanks are the bismuth phosphate process waste, REDOX process waste, PUREX process waste, tri-butyl phosphate or uranium recovery process waste, and saltcake or evaporator bottoms.

Extensive sampling and analysis to address the question have been performed. Statistical evaluation to further address the question will not be performed at this time because it does not support the current planning objectives of the Phase I or II efforts. Sixteen High Priority tanks were originally selected to address the question. Fifty-three tanks were actually sampled and analyzed, of which 12 were High Priority tanks to include 7 of the original selections. The additional 46 High Priority or other tanks provided comparable information to that expected from the 9 tanks originally selected but not used.

3.5.3.1 Background. As part of the effort to characterize Hanford waste and make the characterization process more efficient, tank grouping models have been developed based on process information, transaction history, fundamental chemical and physical principles, and assumptions regarding the behavior of waste in the tanks. The model used as a basis for determining sampling priorities for disposal (Kupfer et al. 1995) was a qualitative model called Sort on Radioactive Waste Type (SORWT) that used waste transfer records (Anderson 1990) to sort tanks into waste type groups. Tanks within a waste type group are expected to have similar chemical compositions.

Although the SORWT model is the historical grouping model discussed in Sections 5.5.3.1, 5.5.5, and Appendix J of Recommendation 93-5 Implementation Plan (DOE-RL 1996), the historical model developed in Hanford Tank Chemical and Radionuclide Inventories: HDW Model Rev. 4 (Agnew 1997) (HDW model) is more recent and incorporates a larger set of transfer and processing records. Use of the SORWT and/or the HDW model is expected to increase the efficiency of characterization activities to further support retrieval, treatment, and immobilization processes.

3.5.3.2 Sampling and Analysis (See Table 3-5). All 149 Hanford Site single-shell tanks have been grouped by the SORWT model into one of 25 groupings. The 25 th group consists of 16 tanks that are expected to be compositionally different from any other tank (they belong to no group). Each of the remaining 128 tanks belongs in one of the other 24 SORWT groups. Of these, 53 tanks have been full-depth sampled with laboratory analysis consisting of at least percent water by thermogravimetric analysis (TGA) or by gravimetry, cations by inductively 
couple plasma (ICP) analysis, and anions by ion chromatography (IC) analysis. These 53 tanks have been sufficiently sampled and analyzed that they may be used to evaluate the ability of the SORWT model to effectively group tanks into distinct waste types.

Further statistical evaluation to compare the models with observed concentrations will not be pursued at this time. Sampling to support Phase I of retrieval, treatment, and immobilization has been already completed. Therefore, no further model/observed concentrations is needed. An evaluation of the SORWT and/or HDW model may be used to support Phase II planning. If so, requirements will be identified through a problem-specific DQO and implemented through the Waste Information Requirements Document (Winkelman et al. 1997) process.

\subsubsection{Sampling and Analysis Summary for Disposal Planning Questions}

Table 3-5 summarizes the sampling and analysis performed for the disposal planning questions. The first column of Table 3-5 lists the tanks that were originally intended to be used for the disposal questions plus other tanks that were actually used. High Priority tanks are denoted with an " $\mathrm{X}$ " in the second column. The sampling status of tanks is shown in the third column. The remaining columns depict which tanks were used for the three disposal questions. Gray shading indicates that, in Appendix F of Recommendation 93-5 Implementation Plan (DOE-RL 1996), a tank was originally intended to be used to address a particular question. The table cells indicate whether a tank was "Used" to adơress a question.

Table 3-5. Sample and Analysis Summary for Disposal Planning Questions. (3 sheets)

\begin{tabular}{|c|c|c|c|c|c|}
\hline & 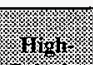 & 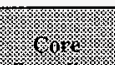 & (6.) & (6) & 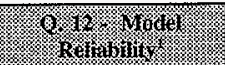 \\
\hline 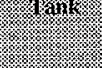 & Poost & Shomoling & 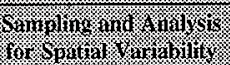 & 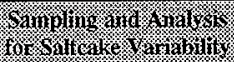 & 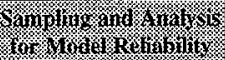 \\
\hline$A-101$ & $\mathrm{X}$ & Sampled & 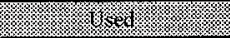 & 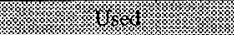 & 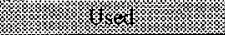 \\
\hline AX-101 & $\mathrm{x}$ & Sampled & . & * & (x) \\
\hline B-104 & $\mathrm{X}$ & Sampled & 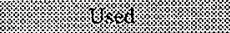 & Used & (x) \\
\hline BY-103 & $\mathrm{X}$ & Unsampled & lin & & \\
\hline BY-104 & $\mathrm{X}$ & Sampled & 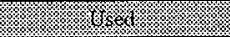 & Vivis & 13. \\
\hline BY-105 & $\bar{x}$ & Sampled & : & (5) & \\
\hline BY-106 & $\bar{x}$ & Sampled & Used & Used & Used \\
\hline BY-108 & $\mathrm{x}$ & Sampled & Used & Used & Used \\
\hline$B Y-110$ & $x$ & Sampled & (1) & 8 & (x) \\
\hline C-104 & $x$ & Sampled & (8) & . & \\
\hline$S-101$ & $\mathrm{x}$ & Sampled & 6 & (3) & 4 \\
\hline S-102 & $x$ & Sampled & 莎 & 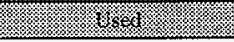 & Used \\
\hline S-107 & $x$ & Sampled & 1 & Used & 135 \\
\hline
\end{tabular}


HNF-2337 Rev. 1

Table 3-5. Sample and Analysis Summary for Disposal Planning Questions. (3 sheets)

\begin{tabular}{|c|c|c|c|c|c|}
\hline \multirow{2}{*}{. } & \multirow{2}{*}{ 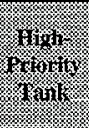 } & \multirow{2}{*}{ - } & (1) & 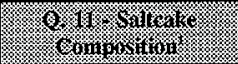 & 8. \\
\hline & & & 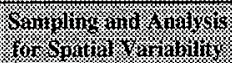 & 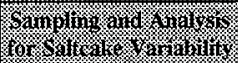 & 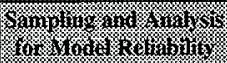 \\
\hline$S-110$ & $\mathrm{x}$ & $\begin{array}{l}\text { Partially } \\
\text { Sampled }\end{array}$ & & & 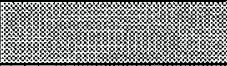 \\
\hline SX-101 & $x$ & Sampled & (1) & & \\
\hline SX-103 & $\mathrm{x}$ & Unsampled & (3) & 筫 & 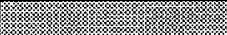 \\
\hline SX-104 & $\mathrm{x}$ & Unsampled & יע: & 4 & 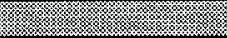 \\
\hline TX-111 & $x$ & Unsampled & & 28. & 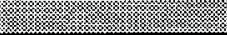 \\
\hline TX-118 & $\mathrm{x}$ & Unsampled & & (2) & 18: \\
\hline U-1032 & $\bar{x}$ & Sampled & Used & Used & Used \\
\hline U-105 & $\mathrm{x}$ & Sampled & 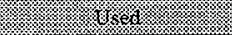 & Used & l: \\
\hline U-107 & $\mathrm{x}$ & Sampled & & Used & \\
\hline $\mathrm{U}-108$ & $\mathrm{x}$ & Sampled & 86rer; & Used & 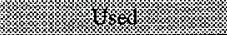 \\
\hline U-109 & $\mathrm{x}$ & Sampled & (1) & 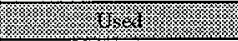 & Used \\
\hline A-102 & & Sampled & Ușed & Used & Used \\
\hline B-106 & & Sampled & Used & Used & Used \\
\hline B-108 & & Sampled & Used & Used & Used \\
\hline B-109 & & Sampled & Used & Used & Used \\
\hline$B-110$ & & Sampled & & & Used \\
\hline B-111 & & Sampled & Used & & Used \\
\hline B-201 & & Sampled & Used & & Used \\
\hline B-202 & & Sampled & Used & & Used \\
\hline B-203 & & Sampled & Used & & Used \\
\hline B-204 & & Sampled & Used & & Used \\
\hline BX-104 & & Sampled & Used & & $U_{\text {sed }}$ \\
\hline BX-107 & & Sampled & Used & & Used \\
\hline BX-109 & & Sampled & $U_{\text {sed }}$ & & Used \\
\hline BX-110 & & Sampled & Used & Used & Used \\
\hline BX-111 & & Sampled & Used & Used & Used \\
\hline $\mathrm{BX}-112$ & & Sampled & Used & & Used \\
\hline BY-101 & & Sampled & & Used & \\
\hline BY-102 & & Sampled & Used & Used & Used \\
\hline BY-107 & & Sampled & Used & Used & Used \\
\hline BY-111 & & Sampled & Used & Used & Used \\
\hline BY-112 & & Sampled & Used & Used & Used \\
\hline C-103 & & Sampled & Used & & Used \\
\hline C-106 & & Sampled & Used & & Used \\
\hline $\mathrm{C}-109$ & & Sampled & Used & & Used \\
\hline
\end{tabular}


Table 3-5. Sample and Analysis Summary for Disposal Planning Questions. (3 sheets)

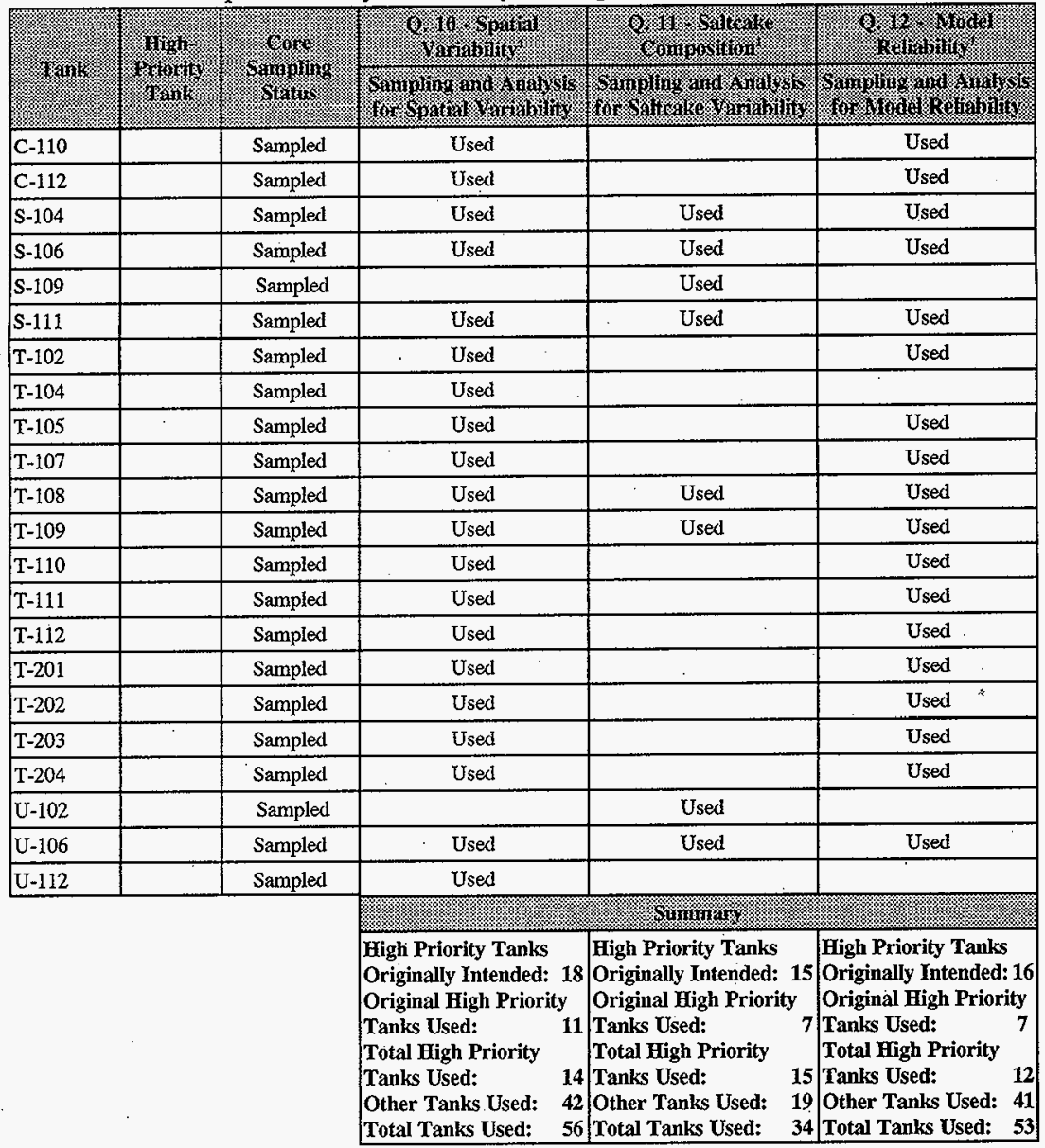

Notes:

'Shading indicates that the tank was originally intended by Appendix F of Recommendation 93-5

Implementation Plan (DOE-RL 1996) to be used to address the question.

${ }^{2}$ Tank U-103 was added to the list of High Priority tanks after the 93-5 Implementation Plan was issued

(Section 3.4 of the attachment to Wagoner [1997]). 
HNF-2337 Rev. 1

\subsection{SAMPLING AND ANALYSIS SUMMARY AND CONCLUSIONS}

\subsection{SUMMARY AND CONCLUSIONS}

Appendix F of Recommendation 93-5 Implementation Plan (DOE-RL 1996) identified 28 High Priority tanks to be core sampled and analyzed near-term to provide scientific and technical data to confirm assumptions, calibrate models, and measure safety-related phenomenological characteristics of tank wastes. Results were to be used to address 12 questions that should be answered allowing key decisions to be made; 9 safety related questions and 3 questions related to planning for the disposal process of retrieval, treatment, and immobilization.

Through sampling and laboratory analysis, all nine safety related questions have been answered and extensive data have been collected for the three disposal planning related questions. Further statistical evaluation of the disposal related data does not support the Disposal Program's current planning needs and will therefore, not be conducted as part of closure for the Implementation Plan.

Twenty-one High Priority tanks were sampled and analyzed and have been used to address the 12 questions. Two additional High Priority tanks have been recently core sampled and are being currently analyzed. The remaining five High Priority tanks have not been sampled due to regulatory requirement delays for rotary-mode core operations. Because rotary-mode sampling could not be used until recently, push-mode core techniques were enhanced and used not only where possible on High Priority tanks, but also on numerous other tanks astutely selected to obtain information to address the 12 questions.

Many more than the 28 tanks originally intended in the Implementation Plan were sampled and analyzed to address the 12 questions. The additional tanks have provided comparable information to that expected from the 7 originally selected tanks not used.

High Priority tanks core sampled and used:

Other tanks core sampled and used:

Other tanks auger or grab sampled and used:

TOTAL tanks condensed-phase sampled and used: 144
21

85

$\underline{38}$

In addition to condensed phase sampling, data from vapor sampling and analysis of 82 tanks (both High Priority and other) were used to answer organic solvent questions needing vapor analysis results.

For a detailed breakout of numbers of tanks sampled and used to address a specific question, refer to Figure 1-1 and/or text and tables throughout the report. 
No further sampling and analysis will be conducted for the sole purpose of addressing the 12 questions in the Implementation Plan. Characterization sampling and analysis will continue in support of other requirements. These activities will be identified through application of the annual, or more frequent as required, robust systems approach process of information requirements identification and tank sampling prioritization described in Section 4.2.

This report is submitted as closure documentation for the DNFSB milestones 5.5.6.1.a and 5.6.3.1.g.

\subsection{FUTURE CHARACTERIZATION}

The enhanced focus on sampling and analyzing High Priority tanks since the Recommendation 93-5 Implementation Plan (DOE-RL 1996) was issued has accelerated addressing safety and disposal questions. However, difficulties have been encountered while focusing on High Priority tank sampling. The High Priority tank list was inflexible to changes in safety and disposal characterization requirements and priorities. As programs sampled and evaluated the High Priority tanks and learned more about their issues, changes in the need and priorities of tanks for sampling inevitably occurred. Sampling from a preset list of tanks did not always allow timely focus on tanks that might have better met program needs.

For future characterization, sampling requirements and plans will be developed from the Tank Characterization Technical Sampling Basis (Brown et al. 1997) and from the Waste Information Requirements Document (Winkelman et al. 1997), both of which will be updated at least annually. These characterization planning documents are the product of an in place working process to focus on near-term safety and disposal (retrieval, treatment, and immobilization) needs. The Tank Characterization Technical Sampling Basis report and the Waste Information Requirements Document are updated after reviewing current requirements with the safety programs, the disposal programs, and other customers of characterization information. 


\subsection{REFERENCES}

Agnew, S. F., 1996, History of Organic Carbon in Hanford HLW Tanks: HDW Model, Rev. 3, LA-UR-96-989, Los Alamos National Laboratory, Los Alamos, New Mexico.

Agnew, S. F., 1997, Hanford Tank Chemical and Radionuclide Inventories: HDW Model Rev. 4, LA-UR-96-3860, Los Alamos National Laboratory, Los Alamos, New Mexico.

Anderson, J. D., 1990, A History of the 200 Area Tank Farms, WHC-MR-0132, Westinghouse Hanford Company, Richland, Washington.

Babad, H., J. E. Meacham, B.C. Simpson, and R. J. Cash, 1993, The Role of Aging in Resolving the Ferrocyanide Safety Issue, WHC-EP-0599, Westinghouse Hanford Company, Richland, Washington.

Babad, H., 1996, Modeling Solvent Low End Vapor Losses During Waste Storage, (internal letter 74E10-96-005 to E. J. Lipke, February 5), Westinghouse Hanford Company, Richland, Washington.

Baldwin, J. H., R. J. Cash, W. I. Winters, L. Amato, and T. Tran, 1996, Tank Characterization Report for Single-Shell Tank 241-BY-108, WHC-SD-WM-ER-533, Rev. 0, Westinghouse Hanford Company, Richland, Washington.

Barney, G. S., 1994, The Solubilities of Significant Organic Compounds in HLW Tank Supernate Solutions, WHC-SA-2565-FP, Westinghouse Hanford Company, Richland, Washington.

Brown, T. M., S. J. Eberlein, and T. J. Kunthara, 1995, Tank Waste Characterization Basis, WHC-SD-WM-TA-164, Rev. 1, Westinghouse Hanford Company, Richland, Washington.

Brown, T. M., J. W. Hunt, and L. J. Fergestrom, 1997, Tank Characterization Technical Sampling Basis, HNF-SD-WM-TA-164, Rev. 3, Lockheed Martin Hanford Corporation, Richland, Washington.

Camaioni, D. M., W. D. Samuels, B. D. Lenigan, S. A. Clauss, K. L. Wahl, and J. A. Campbell, 1994, Organic Tanks Safety Program Waste Aging Studies, PNL-10161, Pacific Northwest Laboratory, Richland, Washington.

Camaioni, D. M., W. D. Samuels, S. A. Clauss, B. D. Lenihan, K. L. Wahl, J. A. Campbell, and W. J. Shaw, 1995, Organic Tanks Safety Program FY95 Waste Aging Studies, PNL-10794, Pacific Northwest Laboratory, Richland, Washington. 
Camaioni, D. M., W. D. Samuels, S. A. Clauss, B. D. Lenihan, K. L. Wahl, J. A. Campbell, and A. K. Sharma, 1996, Organic Tanks Safety Program FY96 Waste Aging Studies, PNL-11312, Pacific Northwest Laboratory, Richland, Washington.

Camaioni, D M., W. D. Samuels, J. C. Linehan, A. K. Sharma, M. O. Hogan, M. A. Lilga, S. A. Clauss, K. L. Wahl, J. A. Campbell, 1998, Organic Tanks Safety Program FY97 Waste Aging Studies, PNNL-11670, Rev. 1, Pacific Northwest National Laboratory, Richland, Washington.

Campbell, J. A., R. M. Bean, K. L. Wahl, G. M. Wong, K. E. Bell, K. B. Wehner, A. D. Rice, R. J. Ray, D. B. Bechtold, B. R. Wels, R. W. Schroeder, J. W. Ball, B. D. Valenzuela, J. M. Frye, S. L. Fitzgerald, P. P. Bachelor, B. Griffin, R. K. Fuller, . B. Benally, and S. M. Parong, 1995, Analysis of Samples from Hanford Waste Tanks 241-C-102, 241-BY-108, and 241-C-103, PNL-10531, Pacific Northwest Laboratory, Richland, Washington.

Campbell, J. A., K. L. Wahl, S. A. Clauss, K. E. Grant, V. Hoopes, G. M. Mong, J. Rau, R. Steele, 1996, Organic Tanks Safety Program: Advanced Organic Analysis FY 1996 Progress Report, PNNL-11309, Pacific Northwest National Laboratory, Richland, Washington.

Carlson, C. D., 1997, Speciation of Organic Carbon in Hanford Waste Storage Tanks: Part I, PNNL-11480, Pacific Northwest National Laboratory, Richland, Washington.

Cash, R. J., 1996a, Cancellation of Ferrocyanide DQO Requirements, (internal letter \#79300-96-031, to S. J. Eberlein on July 22), Westinghouse Hanford Company, Richland, Washington.

Cash, R. J., 1996b, Scope Increase Of 'Data Quality Objective to Support Resolution of the Organic Complexant Safety Issue", Rev. 2, (internal letter \#79300-96-029, to S. J. Eberlein on July 12), Westinghouse Hanford Company, Richland, Washington.

Cash, R. J., 1996c, Application of "Flammable Gas Tank Safety Program: Data Requirements for Core Sampling Analysis Developed Through the Data Quality Objectives Process", Rev. 2, (internal letter $\# 79300-96-028$, to S. J. Eberlein on July 12), Westinghouse Hanford Company, Richland, Washington.

Conway, J. T., 1993, Hanford Waste Characterization Studies, DNFSB Recommendation 93-5, Defense Nuclear Facilities Safety Board, Washington, District of Columbia.

Cowley, W. L., 1997, Organic Solvent Topical, HNF-SD-WM-SARR-036, Rev. 1A, DE\&S Hanford, Inc., Richland, Washington. 
Cowley, W. L. And A. K. Postma, 1996, Analysis of Consequences of Postulated Solvent Fires in Hanford Site Waste Tanks, WHC-SD-WM-CN-032, Rev. 0, Westinghouse Hanford Company, Richland, Washington.

DOE-RL, 1996, Recommendation 93-5 Implementation Plan, DOE-RL 94-0001, Rev. 1, Change 2, U.S. Department of Energy, Richland Operations Office, Richland, Washington.

Dukelow, G. T., J. W. Hunt, H. Babad, and J. E. Meacham., 1995, Tank Safety Screening Data Quality Objective, WHC-SD-WM-SP-004, Rev 2, Westinghouse Hanford Company, Richland, Washington.

Fauske, H. K., M. Epstein, D. R. Dickinson, R. J. Cash, D. A. Turner, and J. E. Meacham, 1995, The Contact-Temperature Ignition (CTI) Criteria for Propagating Chemical Reactions Including the Effect of Moisture and Application to Hanford Waste, WHC-SD-WM-ER-496, Rev. 0, Westinghouse Hanford Company.

Fergestrom, L. J., 1998, [Untitled], (external letter to J. W. Hunt, January 26), Technical Resources International, Inc., Richland, Washington.

Han, F. C., 1996, Structural Integrity and Potential Failure Modes of Hanford High-Level Waste Tanks, WHC-SD-TWR-RPT-002, Rev. 0, Westinghouse Hanford Company, Richland, Washington.

Hodgson, K. M., R. P. Anantatmula, S. A. Barker, K. D. Fowler, J. D. Hopkins, J. A. Lechelt, D. A. Reynolds, D. C. Hedengren, R. E. Stout, and R. T. Winward, 1996, Evaluation of Hanford Tanks for Trapped Gas, WHC-SD-WM-ER-526, Rev. 1, Westinghouse Hanford Company, Richland, Washington.

Huckaby, J. L., J. A. Glissmeyer, J. E. Meacham, and L. A. Stauffer, 1996, Comparison of Organic Constituents Found in the Condensed and Vapor Phases of Tanks 24l-BY-108, 241-BY-110, and 241-C-102, WHC-EP-0919, Rev. 0, Westinghouse Hanford Company, Richland, Washington.

Huckaby J. L., and D. S. Sklarew, 1997, Screening for Organic Solvents in Hanford Waste Tanks Using. Organic Vapor Concentrations, PNNL-11698, Pacific Northwest National Laboratory, Richland, Washington.

Kirkbride, R. A., G. K. Allen, P. J. Certa, A. F. Manuel, R. M. Orme, L. W. Shelton, E. J. Slaathaug, R. S. Wittman, G. T. MacLean, D. L. Penwell, 1997, Tank Waste Remediation System Operation and Utilization Plan, HNF-SD-WM-SP-012, Rev. 0, Numatec Hanford Corporation, Richland, Washington. 
Kupfer, M. J., W. W. Schulz, and J. T. Slankas, 1995, Strategy for Sampling Hanford Site Tank Wastes for Development of Disposal Technology, WHC-SD-WM-TA-154, Rev. 1, Westinghouse Hanford Company, Richland, Washington.

Lilga, M. A., M. R. Lumetta, and G. F. Schiefelbein, 1993, Ferrocyanide Safety Project, Task 3 Aging Studies, FY 1993 Annual Report, PNL-8888, Pacific Northwest Laboratory, Richland, Washington.

Lilga, M. A., E. V. Anderson, M. R. Lumetta, and G. F. Schiefelbein, 1994, Ferrocyanide Safety Project, Task 3: Ferrocyanide Aging. Studies - FY 1994 Annual Report, PNL-10126, Pacific Northwest Laboratory, Richland, Washington.

Lilga, M. A., E. V. Anderson, R. T. Hallen, M. D. Hogan, T. L. Hubleer, G. L. Jones, D. J. Dowalski, M. R. Lumetta, G. F. Schiefelbein, M. R. Telander, 1995, Ferrocyanide Safety Project Ferrocyanide Aging Studies FY 1995 Annual Report, PNL-10713, Pacific Northwest Laboratory, Richland, Washington.

Mahoney, L. A., Z. I. Antoniak, and J. M. Bates, 1997, Composition and Quantities of Retained Gas Measured in Hanford Waste Tanks 241-U-103, S-106, BY-101, and $B Y-109$, PNNL-11777, Pacific Northwest National Laboratory, Richland, Washington.

McDuffie, N. G., 1995, Flammable Gas Tank Safety Program: Data Requirements for Core Sampling analysis Developed Through the Data Quality Objectives Process, WHC-SD-WM-DQO-004, Rev. 2, Westinghouse Hanford Company, Richland, Washington.

Meacham, J. E., 1995, Test Plan for Samples From Hanford Waste Tanks 24l-BY-103, $B Y-104, B Y-105, B Y-106, B Y-108, B Y-110, T Y-103, U-105, U-107, U-108$, and $U-109$, WHC-SD-WM-TP-378, Rev. 0, Westinghouse Hanford Company, Richland, Washington.

Meacham, J. E., R. J. Cash, B. A. Pulsipher, and G. Chen, 1995, Data Requirements for the Ferrocyanide Safety Issue Developed Through the Data Quality Objective Process, WHC-SD-WM-DQO-007, Rev. 2, Westinghouse Hanford Company, Richland, Washington.

Meacham, J. E., 1996a, Increase Scope To Organic DQO, (external letter \#2N160-96-003, to J. G. Kristofzski, Lockheed Martin Hanford Corporation on October 31), Duke Engineering \& Services Hanford, Richland, Washington.

Meacham, J. E., 1996b, Implementation Change Concerning Organic DQO, Rev. 2, (external letter \#2N160-96-006, to Distribution on December 2), Duke Engineering \& Services Hanford, Richland, Washington. 
Meacham, J. E., R. J. Cash, D. R. Dickinson, F. R. Reich, J. M. Grigsby, A. K. Postma, and M. A. Lilge, July 1996, Assessment of the Potential for Ferrocyanide Propagating Reaction Accidents, WHC-SD-WM-SARR-038, Rev. 1, Westinghouse Hanford Company, Richland, Washington.

Meacham, J. E., D. L. Banning, M. R. Allen, and L. D. Muhlestein, 1997a, Data Quality Objective to Support Resolution of the Organic Solvent Safety Issue, HNF-SD-WM-DQO-026, Rev. 0, Duke Engineering \& Services Hanford, Richland, Washington.

Meacham, J. E., A. B. Webb, N. W. Kirch, J. A. Lechelt, D. A. Reynolds, G. S. Barney, D. M. Camaioni, F. Gao, R. T. Hallen, and P. G. Heasler, 1997b, Organic Complexant Topical Report, HNF-SD-WM-CN-058, Rev. 1, Duke Engineering \& Services Hanford, Richland, Washington.

Meyer, P. A., M. E. Brewster, S. A. Bryan, G. Chen, L. R. Pederson, C. W. Stewart, and G. Terrones, 1997, Gas Retention and Release Behavior in Hanford Double-Shell Waste Tanks, PNNL-11536, Rev. 1, Pacific Northwest National Laboratory, Richland, Washington.

Mulkey, C. H. and M. S. Miller, 1997, Data Quality Objectives for Tank Farms Waste Compatibility Program,WHC-SD-WM-DQO-001, Rev. 2, Westinghouse Hanford Company, Richland, Washington.

Noorani, Y. G., 1997, TWRS Basis for Interim Operation, HNF-SD-WM-BIO-001, Rev. 0G, Fluor Daniel Hanford, Richland, Washington.

Osborne, J. W. and L. L Buckley, 1995, Data Quality Objectives for Tank Hazardous Vapor Safety Screening, WHC-SD-WM-DQO-002, Rev. 2, Westinghouse.Hanford Company, Richland, Washington.

Pool, K. H., and R. M. Bean, 1994, Waste Tank Organic Safety Project Analysis of Liquid Samples from Hanford Waste Tank 241-C-103, PNL-9403, Pacific Northwest Laboratory, Richland, Washington.

Postma, A. K., D. B. Bechtold, G. L. Borsheim, J. M. Grigsby, R. L. Guthrie, M. Kummerer, M. G. Plys, D. A. Turner, 1994, Safety Analysis of Ethermic Reaction Hazards Associated with the Organic Liquid Layer in Tank 241-C-103, WHC-SD-WM-SARR-001, Rev. 0, Westinghouse Hanford Company, Richland, Washington.

Scheele, R. D., P. R. Bredt, and R. L. Sell, 1996, Organic Tank Safety Project: Development of a Method to Measure the Equilibrium Water Content of Hanford Organic Tank Wastes and Demonstration of Method on Actual Waste, PNNL-11227, Pacific Northwest National Laboratory, Richland, Washington. 
Scheele, R. D., P. R. Bredt, and R. L. Sell, 1997, Organic Tank Safety Project: Effect of Water Partial Pressure on the Equilibrium Water Content of Waste Samples from Hanford Tank 241-BY-108, PNNL-11401, Pacific Northwest National Laboratory, Richland, Washington.

Schreiber, R. D., 1997, Memorandum of Understanding for the Organic Complexant Safety Issue Data Requirements, HNF-SD-WM-RD-060, Rev. 0, Lockheed Martin Hanford Corporation, Richland, Washington.

Sederburg, J. P., and J. A. Reddick, 1994, TBP and Diluent Mass Balances in the PUREX Plant at Hanford 1955-1991, WHC-MR-0483, Rev. 0, Westinghouse Hanford Company, Richland, Washington.

Shekarriz, A., D. R. Rector, L. A. Mahoney, M. A. Chieda, J. M. Bates, R. E. Bauer, N. S. Cannon, B. E. Hey, C. G. Linschooten, F. J. Reitz, and E. R. Siciliano, 1997, Composition and Quantities of Retained Gas Measured in Hanford Waste Tanks 241-AW-101, $A-101, A N-105, A N-104$, and $A N-103$, PNNL-11450, Rev. 1, Pacific Northwest National Laboratory, Richland, Washington.

Simpson, B. C., and D. J. McCain, 1997, Historical Model Evaluation Data Requirements, HNF-SD-WM-DQO-018, Rev. 2, Lockheed Martin Hanford Corporation, Richland, Washington.

Turner, D. A., H. Babad, L. L. Buckley, and J. E. Meacham, 1995, Data Quality Objective to Support Resolution of the Organic Complexant Safety Issue, WHC-SD-WM-DQO-006, Rev. 2, Westinghouse Hanford Company, Richland, Washington.

Wagoner, J. D., 1997, Transmittal of Defense Nuclear Facilities Safety Board Recommendation 93-5 Implementation Plan Quarterly Report for the Period April 1997 to June 1997, (letter \#97-WSD-180, to J. T. Conway, Defense Nuclear Facilities Safety Board, July 31), U. S. Department of Energy, Richland Operations, Richland, Washington.

Webb, A. B., J. L. Stewart, D. A. Turner, M. G. Plys, B. Malinovic, J. M. Grigsby, D. M. Camaioni, P. G. Heasler, W. D. Samuels, and J. J. Toth, 1995, Preliminary Safety Criteria for Organic Watch List Tanks at the Hanford Site, WHC-SD-WM-SARR-033, Rev. 0, Westinghouse Hanford Company, Richland, Washington.

Winkelman, W. D., M. R. Adams, T. M. Brown, J. W. Hunt, D. J. McCain, and L. J. Fergestrom, 1997, Fiscal Year 1997-1998 Waste Information Requirements Document, Rev. 0, HNF-SD-WM-PLN-126, Rev. 0, Lockheed Martin Hanford Corporation, Richland, Washington. 
HNF-2337 Rev. 1

Wood, T. W., C. E. Willingham, and J. A. Campbell, 1993, Organic Layer Sampling for SST 241-C-103 Background, Data Quality Objectives, and Analytical Plan, PNL-8871, Pacific Northwest Laboratory, Richland, Washington. 


\begin{tabular}{|c|c|c|c|c|c|}
\hline \multicolumn{6}{|c|}{ DISTRIBUTION SHEET } \\
\hline \multirow[b]{2}{*}{ Distribution } & \multirow{2}{*}{\multicolumn{3}{|c|}{$\begin{array}{l}\text { From } \\
\text { Technical Basis and Planning }\end{array}$}} & \\
\hline & & & & \multicolumn{2}{|c|}{$\begin{array}{ll}\text { Page } & 1 \text { of } 1 \\
\text { Date } \quad 03 / 23 / 98\end{array}$} \\
\hline \multicolumn{4}{|l|}{ Project Title/Work Order } & \multicolumn{2}{|l|}{ EDT No. N/A } \\
\hline \multicolumn{4}{|c|}{$\begin{array}{l}\text { HNF-2337, Rev. 1, "High Priority Tank Sampling and Analysis } \\
\text { Report" }\end{array}$} & \multicolumn{2}{|c|}{ ECN No. $\quad$ ECN-635596 } \\
\hline Name & MSIN & $\begin{array}{c}\text { Text } \\
\text { with } \\
\text { Al } \\
\text { Attach. }\end{array}$ & Text Only & $\begin{array}{l}\text { Attach./ } \\
\text { Appendix } \\
\text { Oniy }\end{array}$ & $\begin{array}{l}\text { EDT/ECN } \\
\text { Only }\end{array}$ \\
\hline $\begin{array}{l}\text { Lockheed Martin Hanford Corp. } \\
\text { T. M. Brown } \\
\text { J. W. Hunt } \\
\text { J. G. Kristofzski } \\
\text { M. A. Payne } \\
\text { T.C.S.R.C. }\end{array}$ & $\begin{array}{l}\text { R2-12 } \\
\text { R2-12 } \\
\text { R2-12 } \\
\text { R2-58 } \\
\text { R1-10 }\end{array}$ & $\begin{array}{l}x \\
x \\
x \\
x \\
x\end{array}$ & & & \\
\hline$\frac{\text { Lockheed Martin Services, Inc. }}{\text { Central Files }}$ & $\mathrm{B} 1-07$ & $x$ & & & \\
\hline
\end{tabular}

